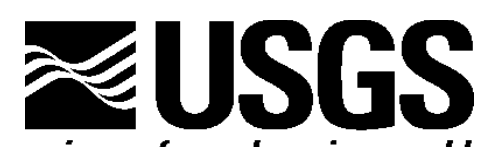

science for a changing world

\title{
Development of a Grazing Monitoring Program for Great Sand Dunes National Park, Colorado
}

By Linda C. Zeigenfuss and Kathryn A. Schoenecker

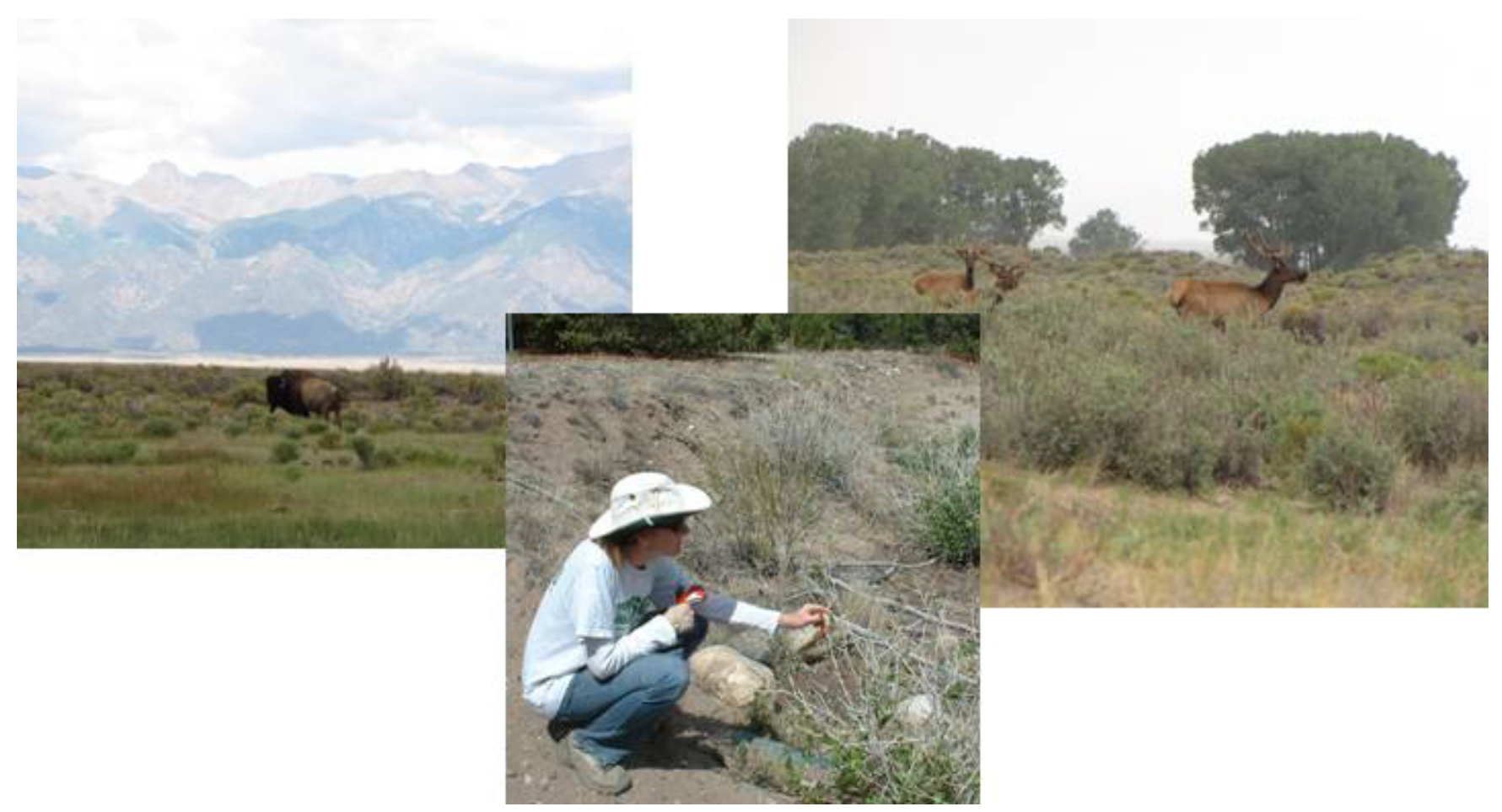

Open-File Report 2015-1136

U.S. Department of the Interior

U.S. Geological Survey 


\section{U.S. Department of the Interior SALLY JEWELL, Secretary}

\section{U.S. Geological Survey \\ Suzette M. Kimball, Acting Director}

U.S. Geological Survey, Reston, Virginia: 2015

For more information on the USGS—-the Federal source for science about the Earth, its natural and living resources, natural hazards, and the environment-visit http://www.usgs.gov or call 1-888-ASK-USGS

For an overview of USGS information products, including maps, imagery, and publications, visit http://www.usgs.gov/pubprod

To order this and other USGS information products, visit http://store.usgs.gov

Suggested citation:

Zeigenfuss, L.C., and Schoenecker, K.A., 2015, Development of a grazing monitoring program for Great Sand Dunes National Park: U.S. Geological Survey, Open-File Report 2015-1136, 44 p., http://dx.doi.org/10.3133/ofr20151136.

ISSN 2331-1258 (online)

Any use of trade, firm, or product names is for descriptive purposes only and does not imply endorsement by the U.S. Government.

Although this information product, for the most part, is in the public domain, it also may contain copyrighted materials as noted in the text. Permission to reproduce copyrighted items must be secured from the copyright owner. 


\section{Contents}

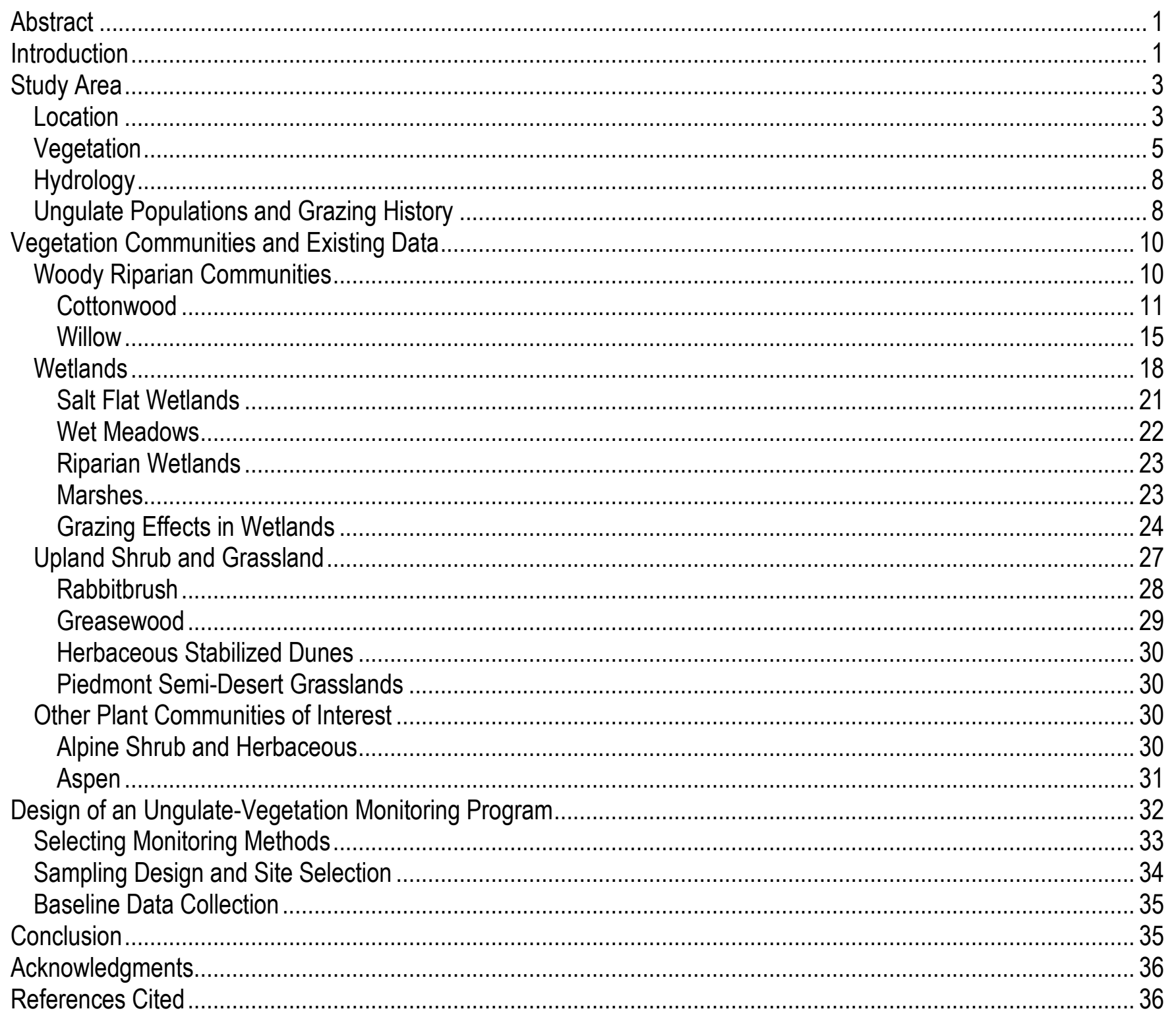

\section{Figures}

1. Land ownership of the Great Sand Dunes region in the San Luis Valley, Colorado. Inset shows study area in relation to landmarks in the state of Colorado

2. Vegetation classifications of ungulate vegetation monitoring study area in Great Sand Dunes National Park, Colorado......

3. Apparent changes in stream channel of lower Sand Creek, Great Sand Dunes National Park and Preserve, Colorado.

4. Additional areas with a significant component of willow identified by 2011 U.S. Geological Survey (USGS) survey in lower Sand Creek compared to vegetation map classification (left) and overlaid on aerial photo (right). 
5. Wetland vegetation map created by the National Park Service Rocky Mountain Vital Signs Monitoring Network (ROMN) correlated to vegetation types of the Salas and others (2011) Great Sand Dunes area vegetation map for the primary concentration of wetlands on and surrounding the Medano

Ranch bison range.

\title{
Tables
}

1. Vegetation types of Great Sand Dunes National Park, Colorado study area as defined by the park vegetation map (Salas and others, 2011), Rocky Mountain Vital Signs Monitoring Network (ROMN) wetland classifications, and pooled into potential monitoring categories

2. Wetland vegetation types created by the National Park Service Rocky Mountain Vital Signs Monitoring Network (ROMN) correlated to vegetation types of the Salas and others (2011) Great Sand Dunes area vegetation map and Schoenecker's (2012) research study classification for the primary concentration of wetlands on and surrounding the Medano Ranch bison range.

\author{
Abbreviations \\ CPW Colorado Parks and Wildlife \\ ESD Ecological Site Description \\ FWS U.S. Fish and Wildlife Service \\ GRSA Great Sand Dunes National Park and Preserve \\ GMP general management plan \\ NRCS Natural Resources Conservation Service \\ NPS National Park Service \\ NWR National Wildlife Refuge \\ ROMN Rocky Mountain Network of NPS Vital Signs Monitoring Program \\ TNC The Nature Conservancy \\ UMP ungulate management plan \\ USGS U.S. Geological Survey \\ WEI wetland ecological integrity
}




\section{Conversion Factors}

SI to Inch/Pound

\begin{tabular}{|c|c|c|}
\hline Multiply & By & To obtain \\
\hline \multicolumn{3}{|c|}{ Length } \\
\hline centimeter $(\mathrm{cm})$ & 0.3937 & inch (in.) \\
\hline meter $(\mathrm{m})$ & 3.281 & foot (ft.) \\
\hline kilometer (km) & 0.6214 & mile (mi) \\
\hline meter $(\mathrm{m})$ & 1.094 & yard (yd.) \\
\hline \multicolumn{3}{|c|}{ Area } \\
\hline square meter $\left(\mathrm{m}^{2}\right)$ & 0.0002471 & acre \\
\hline hectare (ha) & 2.471 & acre \\
\hline square kilometer $\left(\mathrm{km}^{2}\right)$ & 247.1 & acre \\
\hline square centimeter $\left(\mathrm{cm}^{2}\right)$ & 0.001076 & square foot $\left(\mathrm{ft}^{2}\right)$ \\
\hline square meter $\left(\mathrm{m}^{2}\right)$ & 10.76 & square foot $\left(\mathrm{ft}^{2}\right)$ \\
\hline square centimeter $\left(\mathrm{cm}^{2}\right)$ & 0.1550 & square inch $\left(\mathrm{ft}^{2}\right)$ \\
\hline hectare (ha) & 0.003861 & square mile $\left(\mathrm{mi}^{2}\right)$ \\
\hline square kilometer $\left(\mathrm{km}^{2}\right)$ & 0.3861 & square mile $\left(\mathrm{mi}^{2}\right)$ \\
\hline \multicolumn{3}{|c|}{ Volume } \\
\hline cubic meter $\left(\mathrm{m}^{3}\right)$ & 35.31 & cubic foot $\left(\mathrm{ft}^{3}\right)$ \\
\hline cubic meter $\left(\mathrm{m}^{3}\right)$ & 1.308 & cubic yard $\left(\mathrm{yd}^{3}\right)$ \\
\hline \multicolumn{3}{|c|}{ Mass } \\
\hline $\operatorname{gram}(\mathrm{g})$ & 0.03527 & ounce, avoirdupois (oz.) \\
\hline kilogram (kg) & 2.205 & pound avoirdupois (lb.) \\
\hline
\end{tabular}

Temperature in degrees Celsius $\left({ }^{\circ} \mathrm{C}\right)$ may be converted to degrees Fahrenheit $\left({ }^{\circ} \mathrm{F}\right)$ as follows:

${ }^{\circ} \mathrm{F}=\left(1.8 x^{\circ} \mathrm{C}\right)+32$

Horizontal coordinate information is referenced to North American Datum of 1983 (NAD 83)

Altitude, as used in this report, refers to distance above the vertical datum. 


\title{
Development of a Grazing Monitoring Program for Great Sand Dunes National Park, Colorado
}

\author{
By Linda C. Zeigenfuss and Kathryn A. Schoenecker
}

\begin{abstract}
National parks in the United States face the difficult task of managing natural resources within park boundaries that are influenced to a large degree by historical land uses or by forces outside of the park's protection and mandate. Among the many challenges faced by parks is management of wildlife populations that occupy larger landscapes than individual park units but that concentrate within park lands both seasonally and opportunistically. Great Sand Dunes National Park and Preserve in southcentral Colorado is currently developing an Ungulate Management Plan to address management of elk and bison populations within the park. Execution of the Ungulate Management Plan will require monitoring and assessment of habitat conditions in areas that appear sensitive to ungulate use or heavily used by elk and bison. Several sources of information on the various habitats within the park and their use and response to foraging elk and bison exist from recent and on-going research in Great Sand Dunes National Park and Preserve as well as from studies in other regions of the Intermountain West. All of this data can be used to inform the planning process. This report provides background on vegetation types that make up the primary bison and elk ranges in Great Sand Dunes National Park and Preserve and on the potential effects of ungulate grazing and browsing in these specific vegetation communities (both locally and regionally). The report also provides a review of the elements necessary to develop a long-term monitoring program for Great Sand Dunes National Park and Preserve that addresses both the responses to ungulate herbivory seen in important habitats in the park and the amount and patterns of ungulate habitat use.
\end{abstract}

\section{Introduction}

In 2000, the U.S. Congress authorized the expansion of the former Great Sand Dunes National Monument by establishing Great Sand Dunes National Park and Preserve (GRSA) in its place, and establishing the new Baca National Wildlife Refuge (NWR) administered by the U.S. Fish and Wildlife Service (FWS). Great Sand Dunes National Park and Preserve covers 605 square kilometers $\left(\mathrm{km}^{2}\right)$ of land in south-central Colorado extending from the floor of the San Luis Valley to the crest of the Sangre de Cristo Mountains. The area encompassed by this designation protects a number of natural wonders and features including a unique ecosystem of natural sand dunes, the entire watershed of surface and groundwaters necessary to preserve and recharge the dunes and adjacent wetlands, and other valuable riparian and upland vegetation communities that support a host of associated wildlife and bird species.

Bison (Bison bison), elk (Cervus elaphus), mule deer (Odocoileus hemionus), bighorn sheep (Ovis canadensis), and pronghorn antelope (Antilocapra americana) were native to the area until about 
the turn of the 20th century, when bison were extirpated (Meany and Van Vuren, 1993). Elk and pronghorn survived in small numbers (Warren, 1910; Cary, 1911; Swift, 1945). Elk and pronghorn likely moved back into the area from surrounding populations to the north and south, as well as from nearby animal releases by the Colorado Division of Wildlife from the 1910s through the 1960s (Swift, 1945; Colorado Division of Wildlife, 2008), and their populations increased over time. Mule deer populations have varied through time (Cary, 1911; Colorado Parks and Wildlife, 2014). Bison were reintroduced to a limited area of the landscape when a commercial bison herd was established in 1989 on the private Medano and Zapata ranches adjacent to GRSA to the south and west (fig. 1). The Medano-Zapata Ranch and the bison herd are now owned by The Nature Conservancy (TNC) and managed by Ranchlands/Zapata Partners under a contract with TNC. Livestock, including sheep (Ovis aries) and cattle (Bos taurus), were grazed historically throughout the study area, especially in the sand sheet type within the National Park boundary.

In 2009, Great Sand Dunes National Park acquired 7,000 hectares (ha) of Medano Ranch land that adjoins the park and was formerly managed by the State of Colorado (fig. 1). No fences separated these former state lands from other lands on the ranch; thus, bison grazing occurs on the National Park Service (NPS) lands within the Medano Ranch. Wild herds of elk, mule deer, and pronghorn also graze these lands to varying degrees. When the National Park was initially established, there were concerns about over-concentrations of a large and possibly growing elk population and the population's effects on native plant communities. It was anticipated that elk might seek refuge from hunting in the newly expanded park unit and TNC lands where they might over-concentrate and affect unique vegetation communities (Schoenecker and others, 2006). In these sites of potential refugia, or at preferred loafing sites where elk may rest and seek shade, the combined foraging and trampling by elk and bison could accelerate a decline in density, regeneration, and(or) production of woody riparian shrubs and trees as well as affecting understory plants. Elk and bison may also exacerbate possible existing declines that are already occurring due to changes in hydrology, climatic, or dunal processes.

The State of Colorado manages the elk herd outside of NPS and FWS federal lands, whereas the federal agencies are responsible for management of the elk herd on lands under their jurisdiction. Great Sand Dunes National Park is in the process of creating an ungulate management plan (UMP) that will cover management of elk and bison within the park and preserve over the next 20 years (yr). The establishment of a free-ranging herd of 400-1,000 bison on NPS lands has been proposed (U.S. Department of the Interior, 2014a, 2014b); however, it is unknown how a herd ranging over the larger landscape of NPS lands would affect this expanded range. The UMP will incorporate long-term monitoring of the effects of ungulate grazing on habitat condition and potentially population size and distribution of ungulate species.

Management decisions concerning bison and elk could have implications for the density and distribution of ungulates beyond those areas grazed by both species. Singer and Norland (1994) found that when not controlled by predators or human management, bison in Yellowstone National Park expanded their range, thus increasing their habitat breadth and habitat overlaps with other ungulate species (elk, mule deer, and pronghorn). These authors concluded that, while no negative effects on population sizes of other ungulates were observed in response to these increases in bison range, bison habitat breadth and overlap with all other ungulates simultaneously increased bison diet overlap with elk and bighorns. This overlap affected intra- and inter-specific competition (Singer and Norland, 1994). Keller (2011) found high diet and habitat overlap between elk and bison in the Black Hills of South Dakota.

The purpose of this Open-File Report is to provide background on vegetation types that make up the primary bison and elk ranges in GRSA and to describe the potential effects of continued elk and 
bison grazing in these specific vegetation communities (both locally and regionally) at under current population sizes and management, and with increases or decreases in the amount of grazing. This report will also provide information on the elements necessary to develop a long-term monitoring program for GRSA that addresses both the responses seen in important habitats in the park and the amount and patterns of ungulate habitat use. This will assist managers in the development of vegetation condition objectives, identification of potential indicators of ungulate effects on vegetation communities, and creation of grazing-monitoring protocols as the UMP is finalized. The anticipated result would be simultaneous implementation of monitoring and management. The basic elements included here are:

- description of the study area that would likely be encompassed in a GRSA grazing monitoring program;

- identification of vegetation communities in this study area, their ecological value, current condition, and what is known about their use by bison and elk;

- characterization of the response to grazing of these vegetation communities based on available literature and summarization of the available data specific to the study area;

- identification of areas where available data may be lacking;

- description of vegetation monitoring methods being used both within the study area and on adjacent lands, to provide a basis for compatibility and comparability between programs; and

- identification of sources for developing monitoring methods and sampling design specific to a grazing monitoring plan for GRSA.

\section{Study Area}

\section{Location}

Great Sand Dunes National Park and Preserve covers an area of $605 \mathrm{~km}^{2}$ entirely within the San Luis Valley of south-central Colorado. The Park extends from the base of the foothills of the Sangre de Cristo Mountains in the east approximately 20 kilometers $(\mathrm{km})$ across the valley floor to the west between the community of Baca Grande to the north and Alamosa County Lane 6 to the south. The Park boundary includes lands on the Medano Ranch presently owned by The Nature Conservancy. The Baca National Wildlife Refuge bounds the park on the west. The Preserve extends eastward from the Park to the crest of the Sangre de Cristo Mountains (fig. 1). The study area considered here encompasses approximately $413 \mathrm{~km}^{2}$ of Great Sand Dunes National Park below 2,744 meters [m] (9,000 feet [ft]) elevation, and includes the dune field and surrounding lands on the valley floor, as well as roughly 65 percent $(10,482 \mathrm{ha})$ of the current fenced bison range (fig. 1). Some reference is made to higher elevation areas of the Preserve section of GRSA outside this primary study area because these areas contain vegetation types that are highly sensitive, are preferred elk habitat in other regions of the Rocky Mountains, and have been identified as areas of potential concern by GRSA managers.

Precipitation, primarily in the form of rainfall, averages 28 centimeters (cm) annually and falls mostly during monsoonal rains in July through September. Summers are warm with average daytime temperatures ranging from $26.5^{\circ} \mathrm{C}$ to $29.5^{\circ} \mathrm{C}$ on the valley floor. Winters are cold and relatively dry with average valley daytime temperatures ranging from $-9.5^{\circ} \mathrm{C}$ to $1.5^{\circ} \mathrm{C}$. Elevations on the valley floor range from $2,285 \mathrm{~m}$ to $2,744 \mathrm{~m}$. 


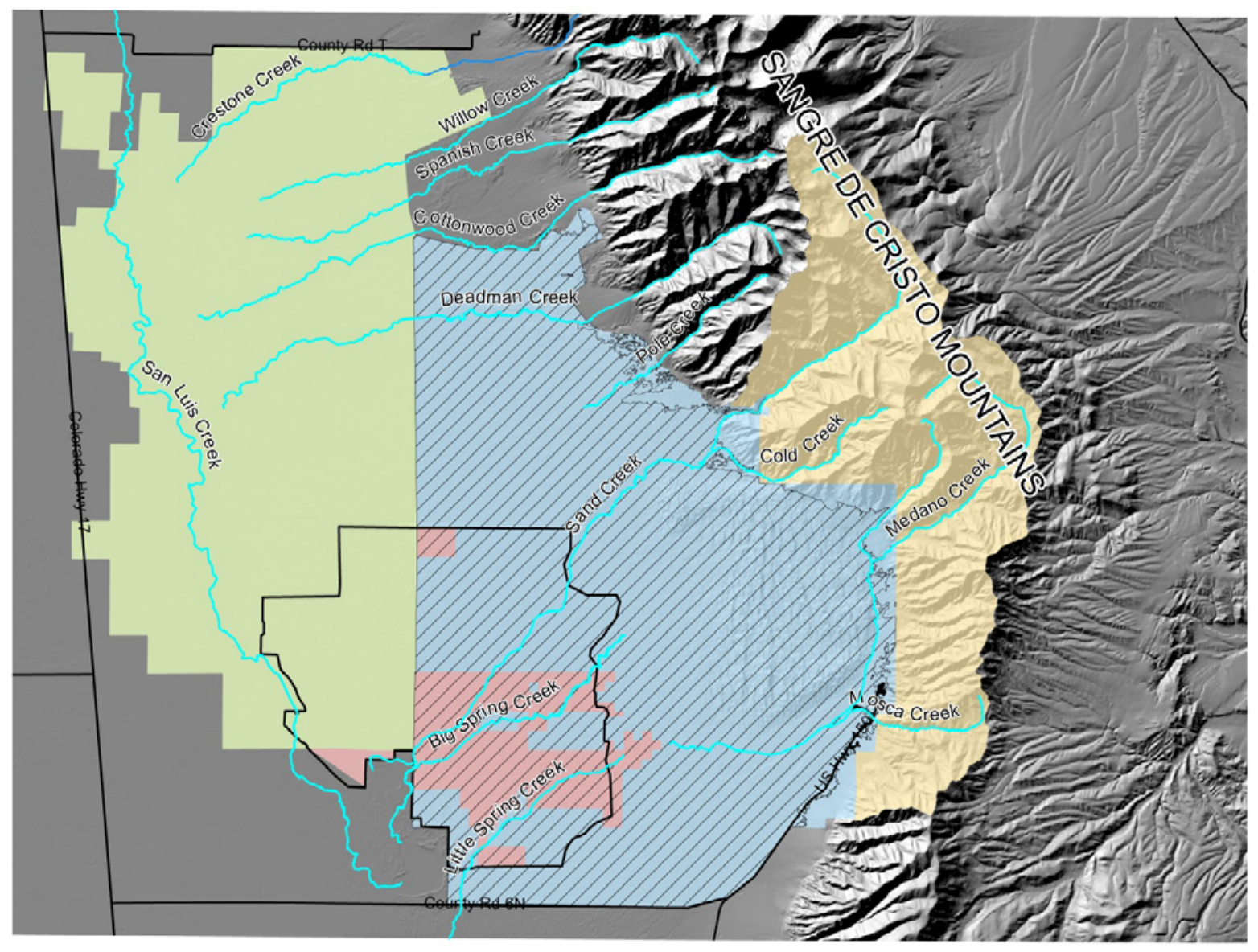
$\hat{\Lambda}$
$\underset{0}{\stackrel{0}{⺊}, \frac{3.25}{2},{ }^{1},{ }^{1}}$
13 KILOMETERS

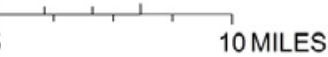

\begin{tabular}{|l|}
\hline \multicolumn{1}{|c|}{ EXPLANATION } \\
Roads \\
- Streams \\
Baca National Wildlife Refuge (USFWS) \\
Great Sand Dunes National Park \\
Great Sand Dunes National Preserve \\
The Nature Conservancy Medano Ranch \\
$\square$ Study Area \\
$\square$ Bison range \\
\hline
\end{tabular}

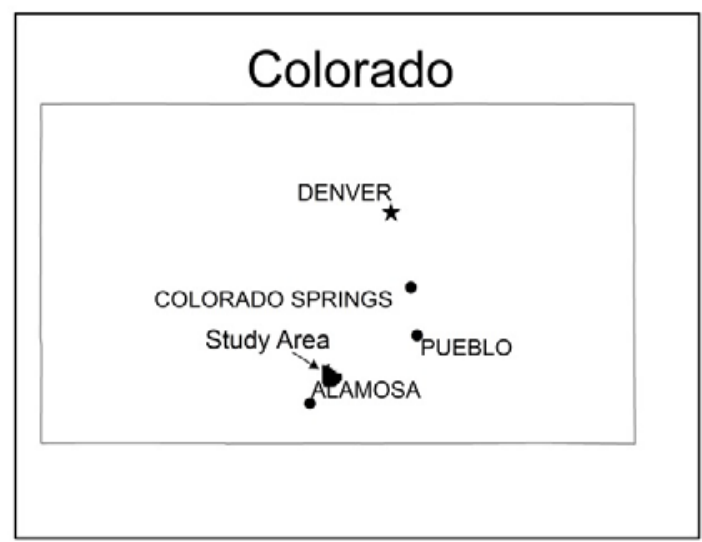

Figure 1. Land ownership of the Great Sand Dunes region in the San Luis Valley, Colorado. Inset shows study area in relation to landmarks in the state of Colorado. (USFWS, U.S. Fish and Wildlife Service) 


\section{Vegetation}

The San Luis Valley is a high elevation desert and lies within the Great Basin desert zone (Barbour and Billings, 1988) and the Southern Rocky Mountains floristic zone (Daubenmire, 1943). West (1988) describes a saltbush (Atriplex canescens)-greasewood (Sarcobatus vermiculatus) vegetation type that dominates lowlands of the upper Rio Grande drainage. The vegetation is correlated with halomorphic (containing salt) soils, where vegetation composition and production is closely linked to soil characteristics (West, 1988). At the lowest elevations of the San Luis Valley, both rabbitbrush (Ericameria/Chrysothamnus spp.) and saltbush/greasewood vegetation types predominate.

The valley landscape contains the highest sand dunes in North America (229 m) with associated vegetation. The sand dunes contain blowout grass (Redfieldia flexuosa) growing in low densities atop the most active dunes. Sand sheet surrounds the active dunes complex to the west, north, and south, and is dominated by greasewood (Sarcobatus vermiculatus) and rubber rabbitbrush (Ericameria nauseosa). Swales are flooded ephemerally during spring from snowmelt off the mountains, and support a dense ground cover of sedges (Carex spp.) and wet meadow grasses. Ephemeral wetlands form the western boundary of the dunes complex and are watered from natural springs and Sand Creek. A large and healthy population of the rare endemic, slender spider flower (Cleome multicaulis), occurs in ephemerally flooded meadows (Dixon, 1971). Cottonwoods (Populus spp.) and willows (primarily coyote willow, Salix exigua) grow atop some dunes, along Sand Creek, portions of Medano Creek, and near springs. Cottonwood stands occurring along Sand Creek are predominantly pure narrowleaf cottonwood (Populus angustifolia), though some limited hybridization with other cottonwood species has been found along Sand Creek (Phyllis Pineda Bovin, Biologist, Great Sand Dunes National Park and Preserve, oral commun., May 2015). Some narrowleaf cottonwoods along Sand Creek have been aged at more than $300 \mathrm{yr}$ old and are among the oldest of this species that have been identified (David Meko, Tree-Ring Research Laboratory, University of Arizona, written commun. to Great Sand Dunes National Monument, 1986). This area is interspersed with wet meadows along creeks and mesic meadows (some formed by irrigation) away from riparian areas. Dominant graminoids include arctic rush (Juncus arcticus), needle-and-thread grass (Hesperostipa comata), Indian rice grass (Achnatherum hymenoides), sand dropseed (Sporobolus cryptandrus), saltgrass (Distichlis spicata), slender wheatgrass (Elymus trachycaulus), and beardless wildrye (Leymus triticoides).

The current park vegetation map (hereafter, the Salas vegetation map) has 48 categories of vegetated lands plus an additional 8 non-vegetated, sparsely vegetated, or developed categories (Salas and others, 2011). However, this map covers $1,673 \mathrm{~km}^{2}$ of NPS, TNC, FWS, USFS, Bureau of Land Management, and private lands, but our study area encompasses only one-fourth of the vegetation map area. Sixteen of the vegetation types occur on the study area (table 1); however, this is many more vegetation types than would be practical to sample based on labor and funding constraints. Additionally, many of these vegetation types are not used to any great extent by either elk or bison, either for foraging or other uses (wallowing, resting, thermal cover, shading), and some of the vegetation types are very similar to one another. One type, Invasive Forbland, is not extensive in the study area (about 2.5 ha) and does not group neatly any with other types. Therefore, it has not been considered further in this analysis. All vegetation types used hereafter are derived from the Salas vegetation map or the NPS Rocky Mountain Vital Signs Monitoring Network (ROMN) protocol for monitoring wetland ecological integrity [WEI] (Schweiger and others, in press). Unfortunately, a precise correlation between Salas' vegetation types and ROMN's wetland classifications is not possible, but the major alignments of types has been listed here (table 1) and will be described in detail in the following sections. 


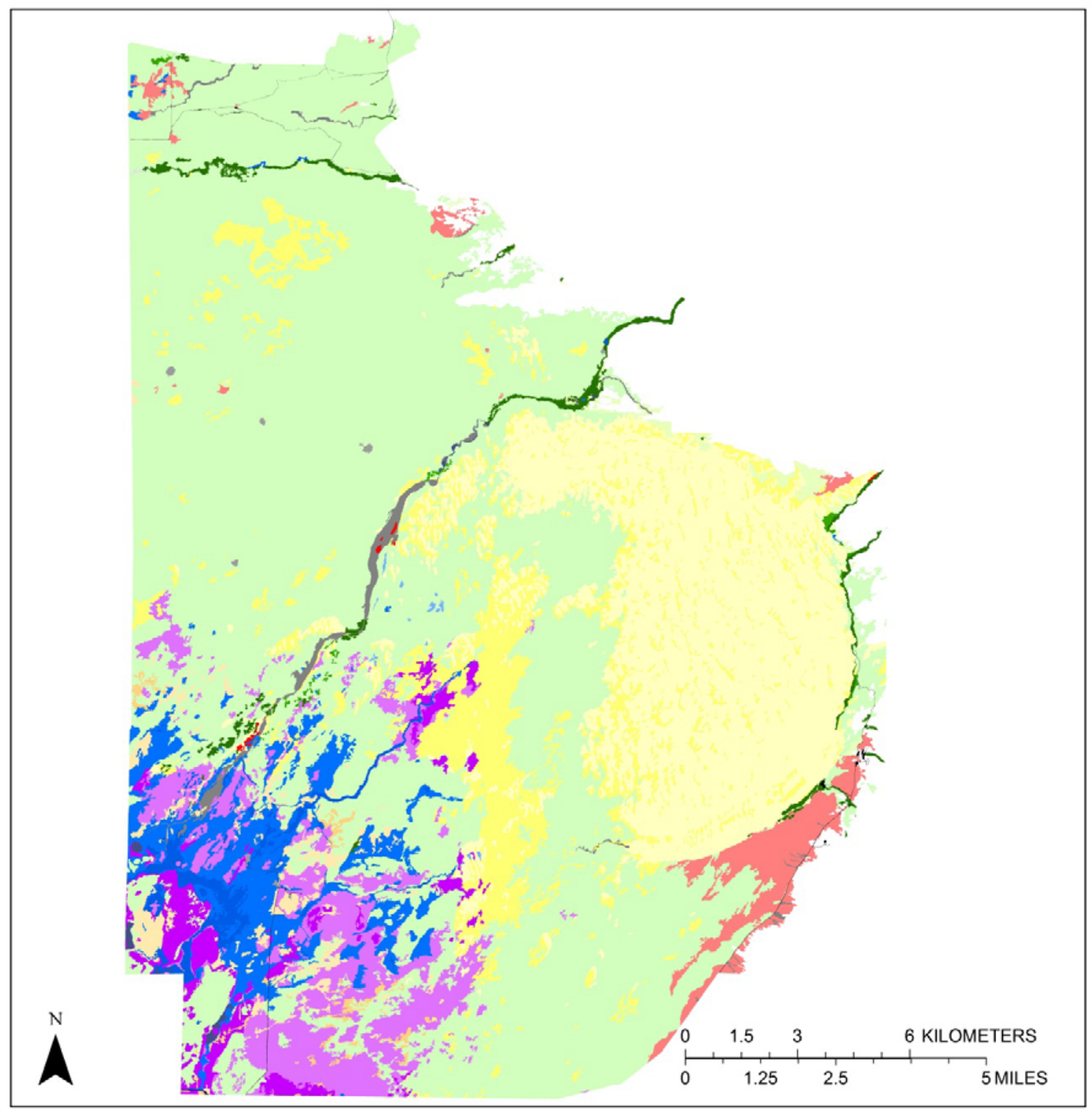

\section{EXPLANATION}

\section{Salas Vegetation Map Classes}

Alluvial Fan Rabbitbrush Shrubland and Steppe Alliances

Alluvial Flat Herbaceous Alliances

Barren Sand Dune

Coyote Willow Temporarily Flooded Shrubland Alliances

Emergent Marsh Alliances

Fourwing Saltbush Shrubland Alliance

Greasewood Flat Shrubland and Steppe Alliances
Greasewood Sand Deposit Shrubland and Steppe Alliances Herbaceous Stabilized Dune and Sandsheet Alliances

Interdunal Swale Wetland Alliances Invasive Forbland

Narrowleaf Cottonwood Sand Dune Woodland Association

Narrowleaf Cottonwood Temporarily Flooded Woodland Alliance
Piedmont Semi-Desert Grassland Alliances

Playa Alliances

Roads

San Luis Valley Mesic Meadow Alliances

Sandsheet Rabbitbrush Shrubland and Steppe Alliances

Urban Residential

Wash

Water

Figure 2. Vegetation classifications of ungulate vegetation monitoring study area in Great Sand Dunes National Park, Colorado. 
Table 1. Vegetation types of Great Sand Dunes National Park, Colorado study area as defined by the park vegetation map (Salas and others, 2011), Rocky Mountain Vital Signs Monitoring Network (ROMN) wetland classifications, and pooled into potential monitoring categories. High use indicates that radiocollared elk and bison were observed in these habitats more than expected based on their availability on the landscape, moderate use indicates expected use was roughly equal to availability of the habitat, and low use indicates that elk and bison use was less than expected based on the amount of available habitat.

\begin{tabular}{|c|c|c|c|c|c|}
\hline $\begin{array}{l}\text { Potential Vegetation } \\
\text { Monitoring Category }\end{array}$ & Vegetation Map "Formal" Classification & ROMN Wetland Classification & Elk use & $\begin{array}{l}\text { Bison } \\
\text { use }\end{array}$ & $\begin{array}{c}\text { Percent } \\
\text { of total } \\
\text { area }\end{array}$ \\
\hline Willow & Coyote Willow Temporarily Flooded Shrubland Alliances & & Low & Low & $<1$ \\
\hline \multirow{3}{*}{ Wetland } & $\begin{array}{l}\text { Emergent Marsh Alliances } \\
\text { Interdunal Swale Wetland Alliances }\end{array}$ & $\begin{array}{l}\text { Riparian wetlands or marsh } \\
\text { Wet meadows }\end{array}$ & High & High & \multirow{3}{*}{7} \\
\hline & $\begin{array}{l}\text { Alluvial Flat Herbaceous Alliances } \\
\text { San Luis Valley Mesic Meadow Alliances }\end{array}$ & & High & High & \\
\hline & Playa Alliances & Salt flat wetlands & Unknown & Seasonal & \\
\hline \multirow{3}{*}{ Greasewood/Saltbush } & Fourwing Saltbush Shrubland Alliance & & & & \multirow{3}{*}{7} \\
\hline & Greasewood Flat Shrubland and Steppe Alliances & & \multirow[t]{2}{*}{ Low } & \multirow[t]{2}{*}{ Low } & \\
\hline & Greasewood Sand Deposit Shrubland and Steppe Alliances & & & & \\
\hline Xeric grass & $\begin{array}{l}\text { Herbaceous Stabilized Dune and Sandsheet Alliances } \\
\text { Piedmont Semi-Desert Grassland Alliances }\end{array}$ & & Moderate & Moderate & 11 \\
\hline Cottonwood & $\begin{array}{l}\text { Narrowleaf Cottonwood Sand Dune Woodland } \\
\text { Association } \\
\text { Narrowleaf Cottonwood Temporarily Flooded Woodland } \\
\text { Alliance }\end{array}$ & & High & Low & 1 \\
\hline Rabbitbrush & $\begin{array}{l}\text { Sandsheet Rabbitbrush Shrubland and Steppe Alliances } \\
\text { Alluvial Fan Rabbitbrush Shrubland and Steppe Alliances }\end{array}$ & & Moderate & Moderate & 56 \\
\hline Non-vegetated & Non-vegetated types (water, barren sand dunes, wash) & & & & 18 \\
\hline
\end{tabular}




\section{Hydrology}

The GRSA study area lies within the Closed Basin of the northern San Luis Valley: a closed hydrologic drainage system with no surface outlet. It is separated from the Rio Grande River by a low ridge. The Closed Basin lies over two aquifers, one shallow (unconfined aquifer) and one deep (confined aquifer; Rupert and Plummer, 2004a). These two aquifers are separated by an 8-ft thick impermeable layer of clay (Rupert and Plummer, 2004b). Five major streams (Deadman Creek, Pole Creek, Sand Creek, Little Spring Creek, and Big Spring Creek) traverse the study area from east to west. Medano Creek wraps around the east side of the dunes, flowing roughly south and west. Flow is seasonal for much of the length of Deadman, Pole, Medano, and Sand creeks once they reach the valley floor. In years when montane snowpack is low, these creeks may disappear underground at their lower reaches. Big Spring and Little Spring creeks are perennial and are still diverted for irrigation on the Medano Ranch. Most of the streams have been manipulated for irrigation at some point in the past century. Medano and Sand Creeks within GRSA infiltrate to recharge the shallow aquifer. Water in the shallow aquifer may be only a few years old, while water in the deep aquifer may be over 30,000 yr old (Rupert and Plummer, 2004b).

Irrigated agriculture was instituted in the $1600 \mathrm{~s}$, but remained small in acreage until the late 1800s. Most irrigation was limited to subirrigation practices until the 1960 s, when it was no longer effective because increased withdrawals from the unconfined aquifer had lowered the water table (Bexfield and Anderholm, 2010). As a result, there was an increase in the use of center pivot irrigation (which draws from the confined aquifer) in the 1970s.

The continued seasonal flow of Medano and Sand creeks is vital to the structure of the sand dunes (Wiegand, 1977; Madole and others, 2008). The flow of these streams rarely extends more than $3.5 \mathrm{~km}$ from the mountain front; however, during peak spring runoff they may flow up to $8 \mathrm{~km}$ from the mountain front (Wiegand, 1977). During floods, sand is eroded from the dunes by the creeks and is carried out toward the sand sheet. After the creeks dry, this sand is blown back into the main dune mass. Vegetation cover and surface water decrease and dune movement increases during droughts (Marín and others, 2005). Increased dune migration can lead to burial and death of herbaceous and woody plants.

\section{Ungulate Populations and Grazing History}

In 2013, an estimated population of 4,400 elk inhabited the $2,819 \mathrm{~km}^{2}$ game-management unit which includes GRSA (roughly 20 percent of the GMU) as well as public and private lands to the north and west of GRSA (Colorado Parks and Wildlife, 2013). Bighorn sheep (Ovis canadensis) are found in small numbers at high elevations of the Preserve section of GRSA (hereafter Preserve). Moose (Alces alces) were reintroduced to the San Juan mountains on the west side of the San Luis Valley in the early 1990s (Colorado Parks and Wildlife, 2014, http://cpw.state.co.us/learn/Pages/LivingwithWildlifeMoose.aspx), and are reported to have been sighted on more than one occasion in the Deadman Creek drainage on the Rio Grande National Forest adjacent to GRSA (Phyllis Pineda Bovin, Great Sand Dunes National Park and Preserve, personal communication, October 2014). Because moose may browse on many sensitive woody plant communities in GRSA (willow, aspen, cottonwood), and there is evidence that they are expanding their range in the state (Colorado Parks and Wildlife, 2014), a potential influx of moose may need to be considered when managing ungulate use in GRSA in the future. Domestic sheep grazing in the San Luis Valley dates back to the early $1800 \mathrm{~s}$; cattle ranching then predominated from the late $1870 \mathrm{~s}$ through recent decades (http://www.zranch.com). From 2005 to 2014 the herd size ranged between 1,500 and 2,400 bison (Schoenecker, 2012) which roamed freely over 16,100 hectares (ha) of the Medano Ranch. 
The former Luis Maria Baca Ranch (hereafter "the Baca"), which makes up the northern part of the Park portion of GRSA and all of the Baca NWR (fig. 1), was actively grazed by 7,000-10,000 cattle through 2004 (Ron Garcia, Refuge Manager, Baca National Wildlife Refuge, written commun., June 2009). The current bison herd was established in 1989 for commercial meat production. In 1999, TNC purchased the ranch and established it as a bison conservation herd, and eventually subcontracted management to a private rancher in 2005.

Ungulate populations in the valley are regulated by hunting, with the exception of bison which are gathered and culled annually to maintain population levels. Bison are restricted by fencing to a 16,100 ha area on the Medano Ranch that lies about half within the boundary of GRSA and half within the boundary of the Baca NWR (fig 1). A joint U.S. Geological Survey (USGS)/NPS elk-bison study collected data on elk and bison movements over several years using both VHF and GPS radiocollars (Schoenecker, 2012). These data were analyzed to determine habitat selection of both elk and bison (Schoenecker and others, in press; Kate Schoenecker, Ecologist, USGS, Fort Collins Science Center, unpublished data), to predict bison density and use on lands outside the current bison range (Schoenecker and others, in press) and to estimate carrying capacity of this landscape under a variety of population scenarios (Wockner and others, 2014). This information was used to determine which vegetation types were incurring the greatest use by elk and bison and that might be considered the highest priority for sampling (table 1).

The bison habitat-selection model (Schoenecker and others, in press) indicated that bison selected wet or mesic grassland habitats year-round and that willow-dominated areas were avoided. Cottonwood communities were also generally avoided except during fall. Playas were selected during summer, likely because of increased herbaceous production while seasonal ponds and wetlands were present, but avoided during other seasons.

The carrying capacity model presented by Wockner and others (2014) suggests that the landscape is currently being grazed by elk between the low threshold of 25 percent consumption of aboveground net primary production (ANPP) and mid-point of 28.5 percent consumption of ANPP. These authors concluded that the available forage for herbivores was not likely being maximally used across the entire landscape. They did caution that hot spots of elk overconcentration or overgrazing may exist due to the uneven distribution of elk across the landscape. Likewise, increased use of a particular area by one ungulate species may cause other ungulate species to use areas they previously avoided.

Wockner and others (2014) also modeled a potential 10 percent reduction in forage due to drought conditions induced by climate change. This change to the model parameters resulted in a substantial reduction in elk carrying capacity, indicating the landscape would support 20 percent fewer elk compared to the current conditions with 2,000 bison, irrigation, haying, and livestock operations on the Baca NWR. These authors noted that other types of changes may also occur that are difficult to estimate, including changes in vegetation composition which could shift elk distribution and(or) migration patterns. Their model results suggested that climate change has the potential to exert a much greater effect on elk carrying capacity than management activities pertaining to elk or bison (Wockner and others, 2014).

Elk use higher elevation areas off the valley floor, but studies of radiocollared elk (Kate Schoenecker, unpublished data) indicate that the greatest concentration of this higher-elevation use occurs north of NPS lands. As a result, grazing in montane and subalpine zones off the valley floor has generally not been considered in the GRSA. However, alpine and aspen habitats in the Preserve have been identified in discussions with park staff as areas of potential concern because they are often targeted by concentrations of elk in other areas of the Rocky Mountains and may not be able to sustain intense elk herbivory over the long-term. Alpine areas, in particular, are highly sensitive to disturbance 
and take long time periods to recover due to short growing seasons, low plant productivity, and environmental stresses, such as wind and extreme cold (Milchunas, 2006; Zeigenfuss, 2006). The effects of elk browsing in aspen communities have been widely documented (Seager and others, 2013). However, conditions in montane and subalpine forests, shrublands, and grasslands, related to elk and other ungulate herbivory, may change with changing animal distribution, population size, and management, or due to current levels of herbivory which may be high enough to accelerate or exacerbate vegetation decline under changing climate conditions. Therefore, managers should be aware of potential herbivory effects in these habitats and respond appropriately through increased monitoring and possibly through management actions if signs of habitat deterioration are observed in these nontarget habitats.

\section{Vegetation Communities and Existing Data}

The following sections describe the main vegetation types found on the valley floor (see table 1), as well as some higher elevation aspen and alpine types. Information specific to research findings in these vegetation types in GRSA has been included when available as well as information about ungulate effects from other locations throughout the Intermountain West.

\section{Woody Riparian Communities}

Woody riparian communities on the valley floor are made up primarily of stands of cottonwood and willow. While some of these communities in GRSA have understory and soil characteristics typical of wetlands, we address wetlands separately from these woody communities. Riparian communities typically support higher densities of insects, particularly butterflies, and may provide more critical habitat for some bat species (Naiman and others, 1993; Swystun and others, 2007) than other plant communities. Cottonwood communities are structurally diverse and have been found to support high densities and richness of breeding birds, including songbirds, raptors, and woodpeckers (Szaro, 1980; Knopf and others, 1988; Krueper and others, 2003; Brand and others, 2008). Similar to cottonwood communities, willow communities provide habitat for a variety of birds, bats, and insects (Scott and others, 2003) and the abundance and diversity of these supported species have been found to be affected by high levels of ungulate herbivory. Anderson (2007) found that willow stands near elk feedgrounds in Wyoming (where elk densities were very high and willow cover was low) had lower avian species richness and relative abundance than areas away from feedgrounds. Willow height was found to be the most important factor explaining songbird species richness and abundance in the Greater Yellowstone region (Olechnowski and Debinski, 2008).

Numerous studies have investigated the effects of elk herbivory on willow and cottonwood, particularly combined with drought or declining water tables, throughout the Rocky Mountains (Keigley, 1997; Singer and others, 1998; Zeigenfuss and others, 2002; Baker and others, 2005; Beschta, 2003, 2005; Bilyeu and others, 2008; Johnston and others, 2011; Rose, 2012). While bison are considered to be primarily grazers, they have been found to browse willows and cottonwoods during summer in Yellowstone National Park at rates that reduce available forage to wintering elk (Painter and Ripple, 2012; Rose, 2012). However, initial studies on diet of elk and bison in GRSA suggest that bison browse very minimally and only seasonally in this arid ecosystem (Kate Schoenecker, Ecologist, USGS, unpublished data). 


\section{Cottonwood}

Roughly 400 ha of narrowleaf cottonwood ( $P$. angustifolia) are located within the GRSA boundary on the valley floor with 20 percent (roughly 80 ha) of these cottonwood stands lying within the bison range of the Medano Ranch. The GRSA General Management Plan (GMP; U.S. Department of the Interior, 2007) identified unhybridized narrowleaf cottonwood stands containing trees up to 340 yr old among the key resources that contribute to the unusual species diversity of GRSA. The park vegetation map defines two types of cottonwood communities: Narrowleaf Cottonwood Sand Dune Woodlands and Narrowleaf Cottonwood Temporarily Flooded Woodlands. These two types are found side-by-side in the study area and have been combined for this discussion. Temporarily flooded woodland alliances are identified as having a moderate to dense herbaceous understory with a diverse complement of understory shrubs (these types are sometimes classified as wetlands by ROMN). Sand dune woodland alliances are found along sand dune ridges and have a sparse herbaceous understory and associated shrub species, and are mainly limited to rabbitbrush and saltbush (Salas and others, 2011). Large trees in cottonwood stands provide the only natural nesting and perching locations for raptors in a valley landscape that is shrub dominated. Dead trees and snags provide nesting and feeding habitats for woodpeckers. Half of all the bird species encountered in a 2005 avian inventory of GRSA, as well as the highest bird densities, were found in riparian habitats (Glenn Giroir, Rocky Mountain Bird Observatory, 2005, unpublished data).

Cottonwoods are dependent on shallow groundwater that is linked to nearby stream water. When groundwater is depleted through dewatering of the associated river or stream via groundwater pumping, irrigation, or drought, this can lead to drought-stress responses in cottonwood, including eventual mortality (Rood and others, 2003). Seedlings require moist soil for germination and establishment, but seedlings and saplings are not tolerant of anaerobic conditions (Amlin and Rood, 2002), so inundation periods must be brief. Growth and development of seedlings is correlated to soil moisture and light, and seedlings do not compete well in vegetated sites (Braatne and others, 1996), so bare ground is optimal for seedling growth. Root growth and seedling establishment is greater in fine, silty sands than coarse, gravelly soils (Braatne and others, 1996). Gradual declines in the water table promote shoot elongation and root growth, but abrupt declines reduce growth and induce mortality (Amlin and Rood, 2002). This makes for a delicate balance for seedling establishment and continued sapling growth and recruitment. Seed rain, wet soils, and gradual water table decline during early growth are all vital to establishment and recruitment of cottonwood, and increased recruitment leads to stand expansion. A limited amount of expansion through root suckers from mature trees may be expected where the canopy allows light infiltration. Excessive browsing of regenerating stems can limit seedling and sucker survival, particularly when environmental conditions for growth are poor. Thus, any vegetation objectives tied to increasing cottonwood stands on the landscape should be carefully considered, as manipulation of ungulate populations alone is unlikely to result in cottonwood stand expansion. Creation or restoration of hydrologic conditions conducive to seedling establishment and growth, as well as removal of competing vegetation, would likely be necessary to provide conditions that would expand the current footprint of cottonwood stands on the landscape and may even be required to maintain existing stands.

Seven research exclosures were erected in cottonwood stands on GRSA or Medano Ranch lands in 2005 as part of a USGS study investigating the effects of elk and bison herbivory in GRSA. Cottonwood tree size and density, sapling density and height, and ungulate browsing levels were monitored from 2005-2009 inside and outside of these research exclosures. Some of these exclosures continue to provide restoration areas for cottonwood saplings, but others had very little regeneration following $5 \mathrm{yr}$ of ungulate exclusion. Based on this research, Schoenecker (2012) determined that GRSA cottonwood communities were sensitive to grazing, because of recent long-term drought 
conditions and changes in hydrologic regimes supporting cottonwood stands. Schoenecker's conclusion was based on evidence of height suppression and decreased sapling density in browsed cottonwoods, and a lack of short-term (5-yr) response in sapling density when browsing was eliminated. Winter herbaceous offtake in cottonwood understory was 31 percent on the bison range compared to 11 percent in park areas with no bison. Mean annual leader use of cottonwood was 46 percent on the bison range and 22 percent on surrounding lands browsed primarily by elk (Schoenecker, 2012). These levels are indicative of light to moderate intensity of grazing (Milchunas and Lauenroth, 1993; Lucas and others, 2004).

Radiocollar studies demonstrated bison avoidance of cottonwood except during the fall (Schoenecker and others, in press), but elk preferred cottonwood areas during most seasons (Kate Schoenecker, Ecologist, USGS, Fort Collins Science Center, unpublished data). Herbaceous biomass is relatively low in cottonwood stands on lower Sand Creek where both ungulates were present, and bison, being primarily grazers, likely prefer the more productive meadows in the area. There is evidence of activity by both ungulates in cottonwood stands (tracks, scat, plant damage from thrashing), and elk were commonly observed in cottonwood sites (personal observation). Lack of telemetry evidence for bison in cottonwood habitats could be due to daytime-only bison location data and nighttime use of these habitats that were not captured by the telemetry study. Data collected using remote cameras located in lower Sand Creek cottonwood and willow habitat indicate that bison travel through these habitat at night, particularly during summer and fall (Kate Schoenecker, Ecologist, U.S. Geological Survey, Fort Collins Science Center, unpublished data). Elk use these areas primarily during the daytime in all seasons, but less elk use of these areas was recorded by cameras from late January through May than June through December.

Analysis of the plant DNA found in fecal samples from bison revealed that bison consume some very small amounts of both willow and cottonwood (averaging 1.1 percent of their entire protein consumption during summer). Analysis of plant DNA found in elk fecal samples revealed a greater proportion of total dietary protein from willow and cottonwood than bison (up to 5 percent in summer).

A USGS study conducted in 2007-2012 (D.C. Andersen, Research Ecologist, U.S. Geological Survey, Fort Collins Science Center, unpublished data) found cottonwood seedlings to be rare or nonexistent along lower Sand Creek on the bison range, and while root suckers were present, they were not abundant. Cottonwood stands in this area have many dead mature trees, missing size classes, and an inverted age structure with many large diameter trees and fewer small diameter trees. Both willow and cottonwood areas on the Medano Ranch have limited aboveground water flow and occur almost exclusively along Sand Creek.

Andersen's study found that 34-82 percent of the variation in radial growth of lower Sand Creek cottonwood trees over the past several decades could be explained by streamflow and climate (D.C. Andersen, Research Ecologist, U.S. Geological Survey, Fort Collins Science Center, unpublished data). While he found no clear evidence of an herbivory effect, he indicated that such an effect is likely masked or manifested elsewhere in the cottonwood stand (for example, sucker production rate). Along Deadman Creek, 20-66 percent of the variation in radial growth could be explained by climate.

While Schoenecker (2012) found that removal of both elk and bison browsing in cottonwood resulted in increased sapling height, other variables such as sapling density and recruitment of cottonwood saplings into the canopy showed mixed results. Removing browse pressure led to increases in sapling density in elk and bison grazed areas, but not in areas with only elk. This may have been due to a number of factors including heavy overstory canopy at some sites which blocked light penetration to the forest floor, a deep water table (at least at one of the four sites; D.C. Andersen, Research Ecologist, U.S. Geological Survey, Fort Collins Science Center, unpublished data), or drought 
conditions that limited seedling and sucker establishment. However, under existing browse pressure, sapling density decreased slightly from 2005-2009 ( $\mathrm{P}=0.048$; Schoenecker, 2012) in three of four sites where only elk were present, but showed no significant change in areas with both elk and bison browsing. Several factors may contribute to observed lack of response to reduced browse pressure. Hydrological characteristics of individual sites may affect the speed with which cottonwoods respond to decreased browse pressure. Also, sites currently grazed only by elk had a recent history of intense cattle grazing which can cause legacy effects. These sites grazed only by elk also had a more closed canopy than sites where bison were present (bison may or may not be a causal factor in the open understory of cottonwood stands on the bison range). Only a limited area of cottonwood exists on the bison range, and bison and elk may concentrate more in these relatively rare stands compared to stands off the bison range. The lack of universal response to removal of browse pressure indicates that additional factors such as history of cattle grazing and water availability are influential.

Gaps in the current knowledge of the park cottonwood stands include: historic extent and origin of cottonwood stands along Sand and Medano creeks, the extent and rate of death of overstory canopy trees, and seed production of these larger trees. It is currently unknown whether the current extent of cottonwood on this landscape is due to natural historic conditions or anthropogenic water manipulations. Previous land owners installed water diversions along lower Sand Creek that may have provided conditions for stand establishment or expansion, or moved water away from existing stands leaving them as remnants with a poor supporting water regime. Anecdotal evidence and aerial photos appear to show an older channel located north of the current channel (fig. 3; David Cooper, Colorado State University, 2009, written commun.) on the other side of existing cottonwood stands. The conditions for seedling establishment for cottonwood may no longer occur at many existing stands due to changes in stream flow, drought, or insufficient seed rain. These factors limit regeneration to root suckers from existing mature trees. Anthropogenic factors (livestock grazing, water manipulation, construction) may also play a role in other areas were cottonwoods appear to be declining, including areas along Medano Creek near the Dunes parking lot, and very small (fewer than 10 trees) remnant stands on lower Big Spring and Deadman creeks.

A substantial amount of dead canopy exists in GRSA cottonwood stands which could be the result of the ongoing drought since approximately 2000. The average percent of dead canopy on trees with a diameter at breast height (dbh) greater than $50 \mathrm{~cm}$ was over 50 percent in areas with bison grazing (Kate Schoenecker and Linda Zeigenfuss, Ecologists, USGS, Fort Collins Science Center, unpublished data). Canopy dieback in cottonwoods has been observed as a response to drought stress over several seasons (Scott and others, 1999; Horton and others 2001a, b; Cooper and others, 2003). However, in stands with closed canopies, this mortality may provide a means for light infiltration to the understory where seedling establishment might occur, provided hydrologic conditions are adequate. The GRSA GMP (U.S. Department of the Interior, 2007) identifies a need to inventory and map cottonwood stands in the park. If a cottonwood inventory is eventually conducted, measures of canopy health and seed rain could be incorporated to identify areas that might be appropriate for restoration. 


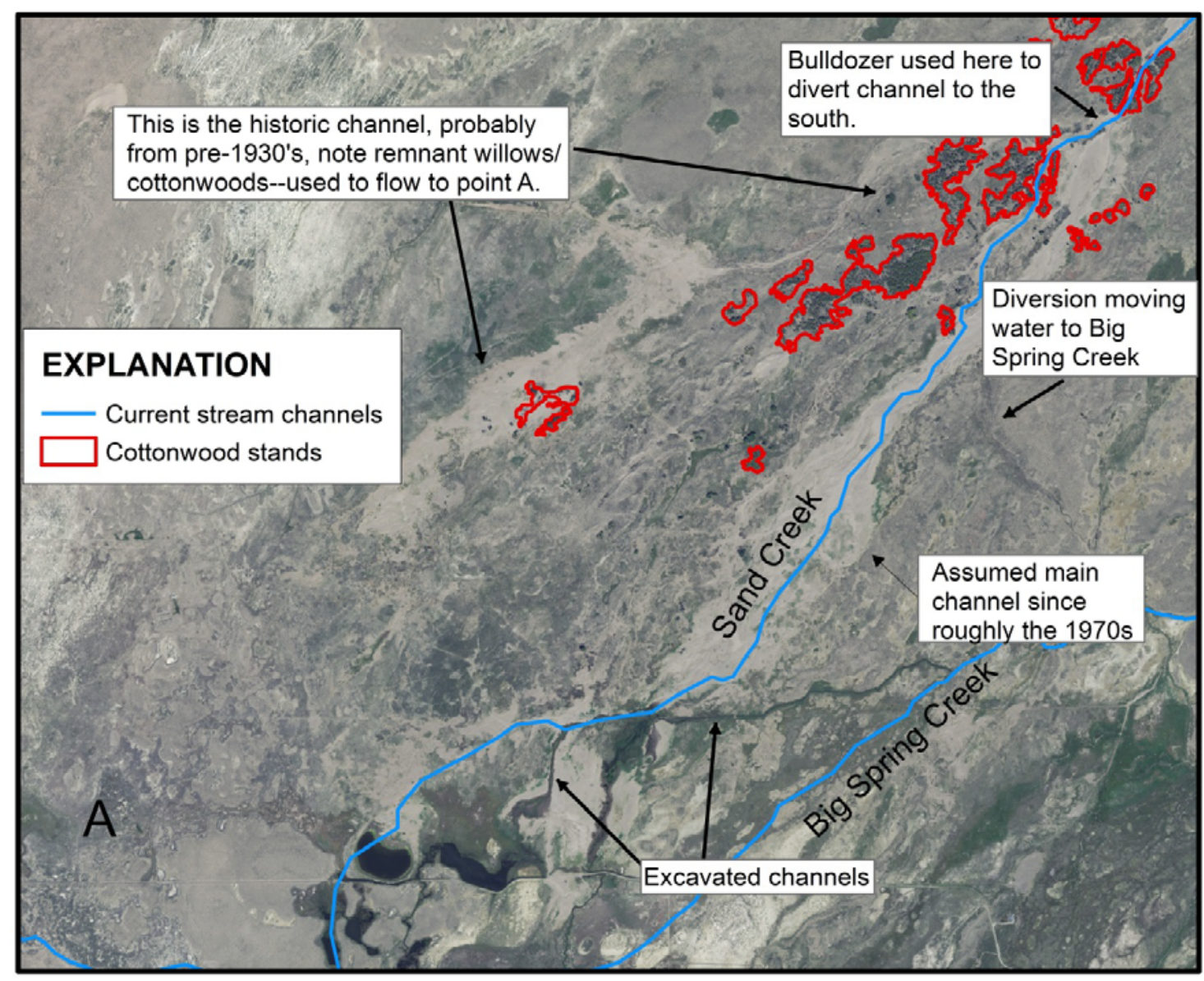

Figure 3. Apparent changes in stream channel of lower Sand Creek, Great Sand Dunes National Park and Preserve, Colorado as identified by David Cooper, hydrologist, Colorado State University.

Maintaining the cottonwood research exclosures could provide further information on long-term effects of ungulate removal, potentially provide seed source if young trees are able to grow and eventually recruit into the canopy, and possibly be used as protected areas for restoration experiments. However, these exclosures require a commitment to maintain as they are subject to compromise from falling trees, sand blowouts that allow ungulate access under the fence, and dune buildup that allows animals to walk over the top of the fence. Without a regular commitment to monitoring and repairing these exclosures, their usefulness for research and monitoring is limited. But even when compromised, enclosures may still be useful for providing some protection to plants within, because usually only a small section of fence is affected and ungulates still need to "find" the access route. Park managers will need to weigh the costs and benefits of continued maintenance of cottonwood research exclosures.

Narrowleaf cottonwood forests are declining in the western U.S. and riparian forests are considered threatened (Noss and others, 1995). If the park determines that cottonwood stands will be a management priority, it is possible that maintenance of stands may require hydrologic manipulations and(or) elimination of browsing by fencing out ungulates until regenerating saplings reach height beyond the reach of browsers. In light of current persistent drought, it may not be possible at all. 
Expansion of existing stands or establishment of new stands would require hydrologic manipulations, protection, and planting of either seeds or cuttings. If park managers decide to manage and protect cottonwoods, management actions could be assessed by monitoring of: (1) the distribution of cottonwood basal area in different stem size classes; (2) browse intensity, height, and density of saplings less than $2.5 \mathrm{~m}$ in height; and (3) seed rain, and seedling establishment and growth, but monitoring hydrologic conditions (wells, soil moisture, local precipitation) would also be necessary to separate the effects of ungulates from hydrology.

\section{Willow}

Coyote willow (Salix exigua) is the predominant willow type within the sand sheet area of GRSA. These willow areas are defined by the park vegetation classification map as "riparian shrubland dominated" or "dominated by coyote willow with other willows (S. ligulifolia, S. lucida ssp. caudata) codominant." Scattered trees (such as cottonwood-less than 10 percent cover) may be present and the understory ranges from barren to abundant forb and graminoid species (Salas and others, 2011). A total of 16 ha of coyote willow are identified in the study area by the vegetation map and a little over half of this area falls inside the bison fence.

Similar to cottonwoods, water availability is a major factor in the decline of willow communities at GRSA (Douglas Anderson, Research Ecologist [emeritus], U.S. Geological Survey, unpubl. data). Recruitment of coyote willow requires gradual recession of water depth to promote root elongation and shoot growth. Willow appears to be even more vulnerable than cottonwood to abrupt water-table declines, but can tolerate anaerobic conditions for a longer time (Amlin and Rood, 2002). Wurster and others (2003) identified climatic variation as well as channel incision along Sand Creek as the major factors in decline of interdunal wetlands at GRSA. Authors found that the Sand Creek channel had narrowed 30-80 percent between 1937 and 1995 (Wurster and others, 2003).

Many areas with a significant willow component are not well represented on the park vegetation map. This may be due to the rarity of willow on the landscape, combined with the fact that coyote willow is often mixed with other shrub species, such as rabbitbrush and greasewood. A rough mapping of willow communities along lower Sand Creek and Medano Creek was attempted by USGS researchers (Linda Zeigenfuss, Kate Schoenecker, Sarah Beck, and Tracy Mask, USGS Fort Collins Science Center) in summer 2011. Many stands of small stature coyote willow mixed with rabbitbrush and greasewood were identified along lower Sand Creek (fig. 4). There was evidence of heavy browsing on most willow in Sand Creek and signs (tracks and scat) indicated extensive elk and bison use of the area. No bison were observed in the area during field visits, but several groups of bull elk were bedded, feeding, and moving through lower Sand Creek at the time of the survey. Along Medano Creek, many patches of willow were located even though none were identified there by the Salas vegetation map. Medano Creek willow appeared healthier (fewer dead stems, lower percentage of dead canopy) compared to Sand Creek willow, and appeared to be subject to lower intensity browsing. However, no quantitative measures were conducted to determine whether Medano Creek willow were, in fact, less decadent with larger, healthier crowns, and had less biomass removed by browsers. Radiocollared elk were rarely observed in the Medano Creek area during the 2005-2009 USGS/NPS study, probably due to high levels of human activity in the Dune Recreation Area (Kate Schoenecker, Ecologist, USGS, Fort Collins Science Center, unpublished data). It is also possible that Medano Creek willow benefit from a more favorable water regime, particularly in terms of precipitation, due to their close proximity to the mountain front. 


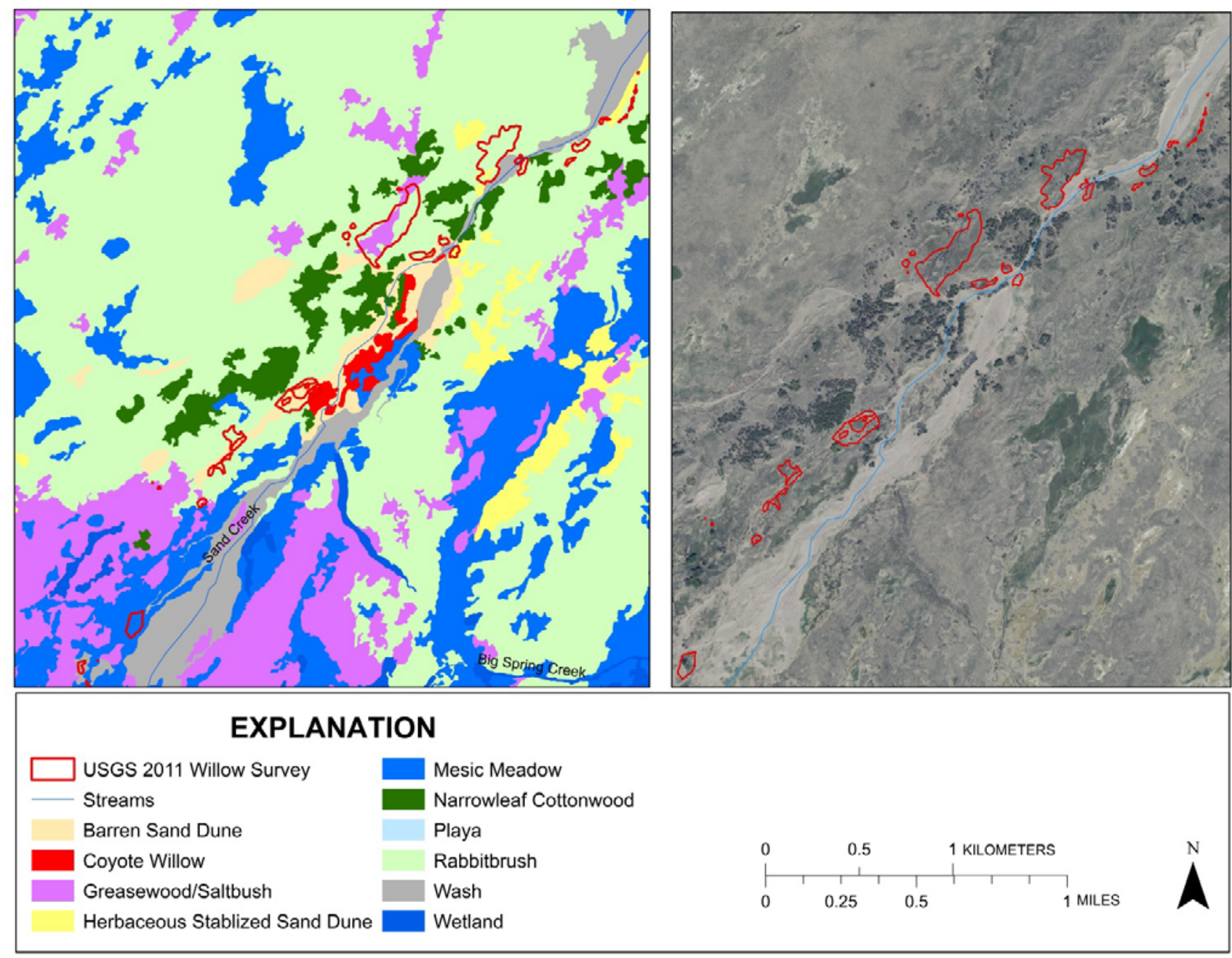

Figure 4. Additional areas with a significant component of willow identified by 2011 U.S. Geological Survey (USGS) survey in lower Sand Creek compared to vegetation map classification (left) and overlaid on aerial photo (right). Areas identified by the vegetation map as coyote willow are accurately represented.

Schoenecker (2012) compared four willow sites on and four sites off the bison range. However, the sites off the bison range were located on the Baca NWR and there was limited comparability between the areas because the Baca NWR sites supported a different suite of willow species, several were in wet meadows or along irrigation channels, and Baca willow were subject to recent livestock grazing and irrigation.

Mean annual woody offtake of willow was 23 percent on Medano Ranch lands used by both elk and bison (Schoenecker, 2012). Although willow species differed in areas only browsed by elk, average annual woody offtake of willow in these areas measured in 2006-2008 was 18 percent (Schoenecker, 2012). The level of offtake on the bison range willow stands was comparable to areas intensively grazed primarily by elk in the Rocky Mountains (roughly 22 percent; Singer and others, 1998, 2002), while offtake on willow sites on the Baca was lower. However, the majority of willow plants on the Baca sites were species other than $S$. exigua and half the sites were along an irrigation ditch which had water actively diverted to it (Schoenecker, 2012). Schoenecker (2012) determined that coyote willows in GRSA responded to removal of ungulate herbivory. Heights of unbrowsed coyote willow were nearly 
twice as tall as browsed willows after $4 \mathrm{yr}$ of removal of ungulate browsing $(\mathrm{P}=0.05)$. Absolute willow canopy area more than doubled in size after $4 \mathrm{yr}$ of protection compared to initial condition, and unbrowsed willow canopy area was 40 percent larger than willow canopy area subject to ungulate herbivory outside the exclosures, though this difference was not statistically significant $(\mathrm{P}=0.43)$, likely due to high variability in willow canopy sizes in sites outside the exclosures. The 4-yr timeframe may have been too short to observe a significant response between types given drought conditions during much of the study.

Analysis of plant DNA found in fecal samples from bison revealed that bison consume very small amounts of willow (up to nearly 1 percent of total protein consumption). Analysis of plant DNA found in elk fecal samples revealed a greater proportion of total dietary protein from willow and cottonwood than for bison. Willow made up a greater proportion of elk dietary protein than cottonwood in summer and winter (K. Schoenecker, unpublished data).

As with cottonwood, the relationship of existing willow stands to their historic footprint on the landscape is difficult to determine. Friedman and others (2006) found that S. exigua occurred mostly on surfaces with an inundation recurrence interval of less than $2.2 \mathrm{yr}$, but because of its poor ability to compete for light and moisture, it did not persist on older and drier sites. Cooper and others (2006) found that greasewood and rabbitbrush invaded playa areas that were no longer subject to frequent inundation following installation of a large irrigation project (Closed Basin Canal) and subsequent ongoing water table drawdown. The mix of willow with rabbitbrush and greasewood in lower Sand Creek may indicate that these areas have been drying or that they are inundated less often than in the past, leading these communities to transition from willow to more xeric shrubs. Wurster and others (2003) concluded that a drier period from 1950 to 1980, along with stream channel incision, led to the disappearance of many interdunal wetlands in the area. However, it is also possible that these mixed communities developed during a period of several years of higher water tables. In this case, the willow might have invaded areas of rabbitbrush when water tables were high and are now reverting back to the previous rabbitbrush dominated condition. Examination of aerial photos or other historic photos, if they exist for these areas, may be able to provide some information on which vegetation type predominated $70-80 \mathrm{yr}$ ago. Analysis of pollen in sediment deposits of Head and San Luis Lakes, which are adjacent to the study area to the west, indicate a cooler and wetter period with arboreal pollen dominance between the mid-1400s and the late 1700s, followed by a drier period from the mid-1800s to the mid1900s dominated by greasewood and chenopod pollen (Jodry and Stanford, 1996).

Given the small areal coverage and uncertain ecological development of $S$. exigua communities in the GRSA ecosystem, managers may need to make a value judgment as to the importance of willow (for example, as bird and insect habitat, or providing stabilization to dunes) on this landscape. It is unclear the degree to which hydrologic changes are limiting willow growth in GRSA. If hydrologic and climatic conditions are ideal, reducing browse pressure might preserve the current condition in willow plant density, canopy cover, and volume, and in areal extent of willow habitats. However, increases in plant cover or height might require protection from browsing while plants recover, and then require exposure to reduced levels of herbivory. As with cottonwoods, expansion of willow would likely require hydrologic manipulations, plant protection from herbivory, and seeding or planting of cuttings to establish new plants. Heavily browsed willow produce fewer catkins and less seed rain than unbrowsed willow (Kay, 1995; Christie and others, 2014), so seed sources outside the experimental exclosures may be limited and would need to be evaluated. Due to the importance of water to cottonwood and willow communities, monitoring of hydrologic variables, such as water table depth, streamflow, and local scale precipitation, will be necessary for managers to determine responses to ungulate management as they relate to hydrologic conditions. 
If park managers desire to assess recovery of these communities in response to ungulate management, monitoring of browse intensity, plant heights, shrub species composition, and shrub canopy cover could be used to determine progress toward recovery in as little as $5 \mathrm{yr}$, but only under favorable conditions (average or above-average precipitation; no substantial disease or insect outbreaks, fires, floods, or other major disturbance). In this semi-arid environment, measurable change may take longer. The existing willow exclosures built in 2005 might be useful as an ungrazed comparison to provide insights into environmental conditions that may confound expected plant responses to ungulate management (drought, disease, changing water availability). However, these exclosures would have to be consistently maintained and the issue of dune buildup along fence lines, which can create conditions conducive to ungulate access to exclosures, would have to be addressed and may ultimately limit their usefulness.

The survival of both cottonwood and willow communities is intricately tied to the water table (Amlin and Rood, 2002; Rood and others, 2003; Friedman and others, 2006; Caplan and others, 2012). Therefore, the influence of drought, drawdown of the unconfined aquifer from irrigation elsewhere in the San Luis Valley, and channel incision on Sand Creek and Deadman Creek (and possibly Medano, Cottonwood, Pole, and Short creeks) cannot be easily separated from any ungulate management actions. Monitoring of variables related to water availability, such as depth to water table, streamflow, and snowpack and precipitation, will be needed as covariates in any analyses of responses of cottonwood and willow communities to ungulate management actions.

\section{Wetlands}

Wetlands are areas where water is present either at or near the surface of the soil either seasonally or year-round, including during the growing season. In these communities, water is the dominant feature that determines soil development and animal and plant species composition (Cowardin and others, 1979). Wetlands present one of the more challenging vegetation types to identify using the vegetation map. Only two vegetation types are identified by the Salas vegetation map as "wetland" in the valley floor GRSA study area-Emergent Marsh Alliances and Interdunal Swale Wetland Alliances. However, the vegetation types identified as San Luis Valley Mesic Meadow Alliances and Playa Alliances also fit well within the description of wetlands. Together, these vegetation types total 2,834 ha on the study area with 95 percent of these wetlands (2,681 ha) on the bison range. However, ROMN WEI monitoring program has determined that the current park vegetation map is too coarse to accurately identify many wetland areas in the park (E.W. Schweiger, Ecologist, Rocky Mountain Network, Vital Signs Monitoring Program, National Park Service, written commun., March 2015). The Rocky Mountain Network WEI program identifies four wetland types in the GRSA study area: Salt Flat Wetlands, Wet Meadows, Marshes, and Riparian Wetlands and they have developed a map that provides preliminary categorization of wetlands (fig. 5) However, this map has only been verified at sites that have been selected for WEI monitoring, and corrections based on these site visits have not been applied to this map. The ROMN wetland map identifies a total of 3,064 ha of wetlands in the study area with 2,635 ha (86 percent) within the bison range. The current ROMN WEI wetland map could be updated using the information already gathered as part of the WEI sampling for identifying potential wetland monitoring sites as part of a future grazing monitoring plan. Because vegetation categories in the Salas vegetation map do not correlate exactly to the ROMN wetland map (fig. 5, table 2), we used the ROMN classifications as the main wetland subcategories described below, then referenced to the greatest extent possible correlations to the Salas vegetation map and the Schoenecker (2012) study. 


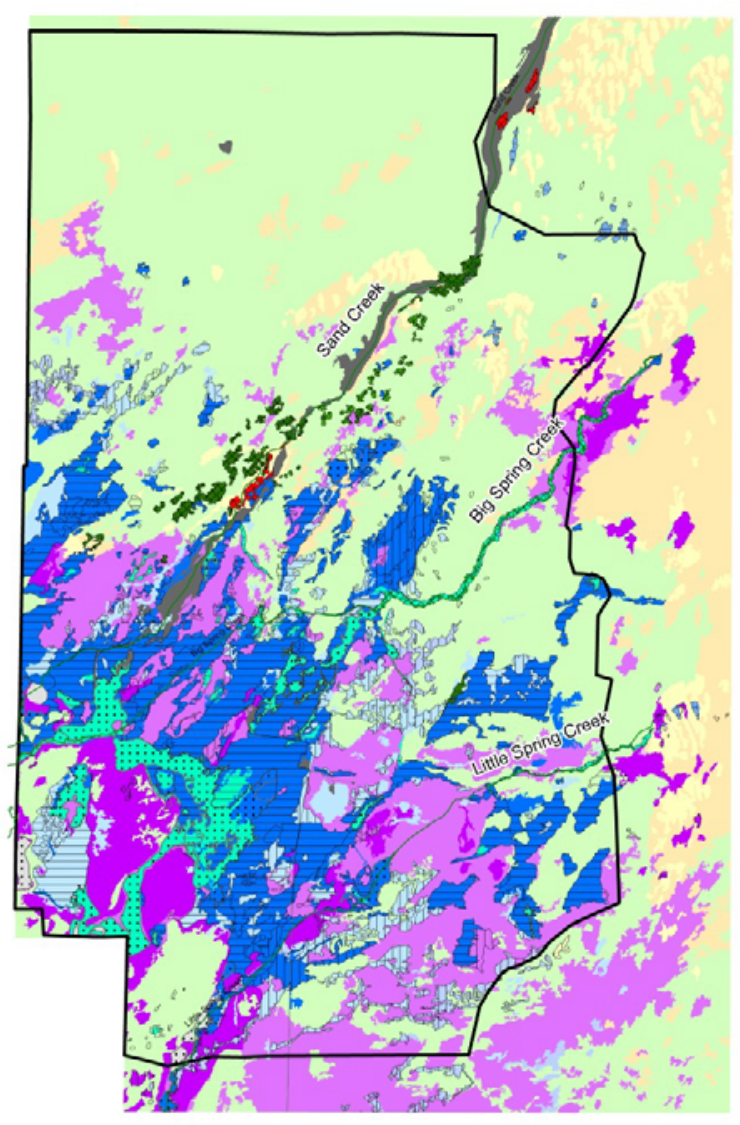

\section{EXPLANATION}

- Streams

$\square$ Bison Range

ROMN Wetland Types

(:i.:i:.) Marsh

Riparian

\IIIT! Salt flat

Wet meadow

Salas Vegetation Types

Alluvial Flat Herbaceous Alliances

Barren Sand Dune

Coyote Willow Temporarily Flooded Shrubland Alliances

Emergent Marsh Alliances

Fourwing Saltbush Shrubland Alliance

Greasewood Flat Shrubland and Steppe Alliances

Greasewood Sand Deposit Shrubland and Steppe Alliances Herbaceous Stabilized Dune and Sandsheet Alliances

Interdunal Swale Wetland Alliances

Narrowleaf Cottonwood Sand Dune Woodland Association

Narrowleaf Cottonwood Temporarily Flooded Woodland Alliance

Playa Alliances

Roads

San Luis Valley Mesic Meadow Alliances

Sandsheet Rabbitbrush Shrubland and Steppe Alliances

Urban Residential

Wash

Water

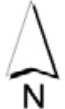

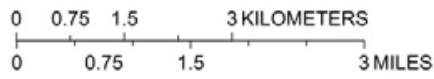

Figure 5. Wetland vegetation map created by the National Park Service Rocky Mountain Vital Signs Monitoring Network (ROMN) correlated to vegetation types of the Salas and others (2011) Great Sand Dunes area vegetation map for the primary concentration of wetlands on and surrounding the Medano Ranch bison range. 
Table 2. Wetland vegetation types created by the National Park Service Rocky Mountain Vital Signs Monitoring Network (ROMN) correlated to vegetation types of the Salas and others (2011) Great Sand Dunes area vegetation map and Schoenecker's (2012) research study classification for the primary concentration of wetlands on and surrounding the Medano Ranch bison range. Bold denotes primary Salas class contributing to ROMN class. $(<$, less than)

\begin{tabular}{|c|c|c|c|}
\hline $\begin{array}{l}\text { ROMN Wetland } \\
\text { Classification }\end{array}$ & Salas Vegetation Map Classification & $\begin{array}{l}\text { Schoenecker } \\
\text { Classification }\end{array}$ & $\begin{array}{l}\text { Percent Contribution } \\
\text { of Salas Class to } \\
\text { ROMN Class }\end{array}$ \\
\hline \multirow[t]{6}{*}{ Marsh } & Emergent Marsh Alliances & & 75 \\
\hline & $\begin{array}{l}\text { San Luis Valley Mesic Meadow Alliances } \\
\text { /Emergent Marsh Alliances mix }\end{array}$ & & 9 \\
\hline & San Luis Valley Mesic Meadow Alliances & & 10 \\
\hline & Playa Alliances & & $<1$ \\
\hline & Water & & 6 \\
\hline & Greasewood Alliances & & $<1$ \\
\hline \multirow[t]{4}{*}{ Riparian } & $\begin{array}{l}\text { Narrowleaf Cottonwood Sand Dune } \\
\text { Woodland Association } \\
\text { Narrowleaf Cottonwood Temporarily } \\
\text { Flooded Woodland Alliance }\end{array}$ & Cottonwood & 83 \\
\hline & Emergent Marsh Alliances & Wet meadow & 13 \\
\hline & $\begin{array}{l}\text { Coyote Willow Temporarily Flooded } \\
\text { Shrubland Alliances }\end{array}$ & Willow & 3 \\
\hline & San Luis Valley Mesic Meadow Alliances & & $<1$ \\
\hline Salt Flat & Alluvial Flat Herbaceous Alliances & & 39 \\
\hline \multirow{10}{*}{ Wetlands } & San Luis Valley Mesic Meadow Alliances & & 23 \\
\hline & Playa Alliances & & 20 \\
\hline & $\begin{array}{l}\text { San Luis Valley Mesic Meadow Alliances / } \\
\text { Playa Alliances mix }\end{array}$ & & 6 \\
\hline & $\begin{array}{l}\text { Alluvial Flat Herbaceous Alliances / San } \\
\text { Luis Valley Mesic Meadow Alliances } \\
\text { mix }\end{array}$ & & 5 \\
\hline & $\begin{array}{l}\text { Alluvial Flat Herbaceous Alliances / Playa } \\
\text { Alliances mix }\end{array}$ & & 3 \\
\hline & Emergent Marsh & & $<1$ \\
\hline & $\begin{array}{l}\text { Greasewood Flat Shrubland and Steppe } \\
\text { Alliances }\end{array}$ & & 3 \\
\hline & $\begin{array}{l}\text { Greasewood Sand Deposit Shrubland and } \\
\text { Steppe Alliances }\end{array}$ & & \\
\hline & Sandsheet Rabbitbrush & & 1 \\
\hline & $\begin{array}{l}\text { Greasewood Alliances /San Luis Valley } \\
\text { Mesic Meadow Alliances }\end{array}$ & & $<1$ \\
\hline \multirow[t]{9}{*}{ Wet Meadow } & San Luis Valley Mesic Meadow Alliances & Mesic meadow & 85 \\
\hline & Alluvial Flat Herbaceous Alliances & & 7 \\
\hline & $\begin{array}{l}\text { San Luis Valley Mesic Meadow Alliances } \\
\text { /Alluvial Flat Herbaceous Alliances }\end{array}$ & & 3 \\
\hline & $\begin{array}{l}\text { San Luis Valley Mesic Meadow Alliances/ } \\
\text { Greasewood Alliances }\end{array}$ & & 1 \\
\hline & $\begin{array}{l}\text { San Luis Valley Mesic Meadow Alliances } \\
\text { /Emergent Marsh Alliances }\end{array}$ & & 1 \\
\hline & Interdunal Swale Wetland Alliances & & 2 \\
\hline & Emergent Marsh Alliances & & $<1$ \\
\hline & $\begin{array}{l}\text { Sandsheet Rabbitbrush Shrubland and } \\
\text { Steppe Alliances / Greasewood Alliances }\end{array}$ & & $<1$ \\
\hline & Other & & $<1$ \\
\hline
\end{tabular}




\section{Salt Flat Wetlands}

Salt flats are identified by the ROMN WEI protocols (Schweiger and others, in press) as a widespread wetland type at low elevations forming in closed basins west of the dune field with heavy textured soils or where evaporation from a high water table promotes the accumulation of salts. Productivity is generally low, and species composition is limited to salt-tolerant species including saltgrass, greasewood, and saltbush. There is considerable variability in hydrologic characteristics; water levels fluctuate widely both seasonally and among years, with extended periods of deep inundation alternating with periods where surface water may be completely absent (Cooper and Severn, 1992). Salt flats may also be influenced by groundwater, through direct discharge in discrete springs or through capillary movement of water from seasonally high water tables. Both high-water periods and multi-year droughts can lead to high plant mortality.

Nearly all the areas identified as Playa Alliances on the Salas and others (2011) vegetation map are included in ROMN's salt flat wetlands. Because they seasonally hold water and may therefore have green vegetation later into the summer when herbaceous vegetation in surrounding areas has already senesced, they may provide local hotspots for grazing by both bison and elk. In other landscapes with playas where livestock grazing is present, livestock often congregate in playas because of early growth of plants, increased plant production, and favorable microclimate during harsh weather (Haukos and Smith, 2003). This can subject playa vegetation to reductions through consumption and trampling by livestock. In general, playa lakes are important to waterfowl and other migrating birds, providing food, cover, and resting habitat. Bison do appear to slightly favor these playa areas during summer (Schoenecker and others, in press); however, we have little information on elk use of these areas. Although the San Luis Valley does not receive as many migrant shorebirds as other areas such as the Great Basin and Playa Lakes regions, playas within the San Luis Valley still provide important migration habitat for many shorebird species (U.S. Department of the Interior, 2014a).

During dry years many of these playas remain dry, but they still have high productivity. When water is available, playas fill during spring runoff and thunderstorms, and then dry slowly over the summer. This drying and wetting cycle provides for the nutrient cycling conditions ideal for the production of invertebrates, a valuable food resource for numerous vertebrate species (U.S. Department of the Interior, 2005). When precipitation is above average, these wetlands are some of the most productive in the area (Cooper and Severn, 1992). Saltgrass pans are important habitat for several rare species of small mammals and the sandhill skipper (Polites sabuleti ministig), a rare butterfly subspecies (U.S. Department of the Interior, 2005).

Two other Salas and others (2011) vegetation types are heavily represented in the Salt Flat Wetlands-Alluvial Flat Herbaceous Alliances and San Luis Valley Mesic Meadow Alliances (see description in following section). These types, along with Playa Alliances, make up 94 percent of the Salt Flat wetlands type used by ROMN (table 2). The Salas map describes San Luis Valley Mesic Meadows as having a moderately dense to dense herbaceous layer dominated by native species such as saltgrass, sedges (Carex pellita, C. praegracilis), foxtail barley (Hordeum jubatum), arctic rush, beardless wildrye, scratchgrass (Muhlenbergia asperifolia), spike muhly (M. wrightii), western wheatgrass (Pascopyrum smithii), muttongrass (Poa fendleriana), Nuttall's alkaligrass (Puccinellia nuttalliana), alkali sacaton (Sporobolus airoides), silverweed (Argentina anserina), slender spiderflower (Cleome multicaulis), Rocky Mountain iris (Iris missouriensis), and woolly cinquefoil (Potentilla hippiana). Alluvial Flat Herbaceous Alliances are saltgrass-dominated patches within greasewood shrublands that may transition into San Luis Valley Mesic Meadows. 


\section{Wet Meadows}

The ROMN WEI protocols (Schweiger and others, in press) identify wet meadows as areas that typically exhibit seasonally saturated soils, but lack the large seasonal and interannual water table fluctuations characteristic of marshes. Wet meadow soils are mineral, but have significantly more organic matter than soils in the surrounding upland. Mineral soils often have lower water-holding capacity than peat and mineral substrates, and may drain and dry more readily than peaty soils, but also have higher levels of nutrient availability. Wet meadow species include arctic rush, alkali sacaton, and sedges. Shrubs (commonly Salix) and trees may be present, but canopy cover is usually low. Conditions such as moist, unsaturated mineral soils, and high levels of nutrient availability in wet meadows often support high cover and diversity of exotic species (Stohlgren and others, 1999). Introduced perennial sod-forming grasses such as creeping bentgrass (Agrostis stolonifera) and redtop (A. gigantean) are common dominants, particularly at lower elevations and in wet meadows adjacent to riparian areas. Pasture grasses, such as Kentucky bluegrass (Poa pratensis) are also present in meadows affected by livestock and historic homesteading.

Wet meadows frequently occur in stream valleys as part of larger wetland complexes, although unlike riparian wetlands, wet meadows are not subject to high-velocity surface flows or sediment deposition from fluvial processes. Wet meadows typically occur in sites where soils are seasonally saturated; however, unlike fens or marshes, perennially high water tables or seasonal flooding does not typically occur. High water levels are common early in summer, but water tables in wet meadows may drop to $1 \mathrm{~m}$ or more below the soil surface in late summer. Precipitation and groundwater flows are likely the most important contributors to hydrologic regimes of wet meadows. Local and regional aquifers contribute groundwater by creating shallow water tables along aquifer flow paths or discharging directly to the soil surface. This is especially true during spring snowmelt when aquifers are swollen, and spring melt water may be the primary source of seasonal inundation for wet meadows in dry areas. Direct surface water inputs to wet meadows are generally limited to rainfall and sheet flow following extreme precipitation or snowmelt events and may have a greater effect in middle to late summer when groundwater flows are diminished (from Schweiger and others, in press).

Most areas identified as San Luis Valley Mesic Meadows on the Salas vegetation map fall within the ROMN wet meadow classification (fig. 5). Also included under the ROMN wet meadow classification are saltgrass-dominated areas identified on the Salas vegetation map as Alluvial Flat Herbaceous Alliances, as well as Interdunal Swale Wetland Alliances. Interdunal wetlands are nonriparian wetlands that form in arid sand dune environments at locations where the regional water table intersects the ground surface (Wurster and others, 2003). The vegetation map defines interdunal wetlands as groundwater-fed wetland vegetation that occurs in distinctive interdunal swales (deflation areas between active dunes) with shallow water tables not visibly connected to other surface water. These sites occasionally have stands of coyote willow that persist during sand burial as dune encroachment occurs (Salas and others, 2011). However, some areas within these interdunal wetlands, particularly around Elk Springs, fall under the ROMN classification for marshes.

Wet meadows are typically associated with springs and are naturally subirrigated, but their footprint has also been expanded by historic and ongoing (by Ranchlands/Zapata Partners) irrigation. The GRSA General Management Plan (U.S. Department of the Interior, 2007) proposes cessation of irrigation and potential restoration of natural hydrologic regime on the Medano Ranch, if and when, TNC ceases agricultural uses of the Medano ranch. When the NPS assumed management of new lands on the former Baca and current Medano ranches, there were several existing free-flowing wells that were not in compliance with Colorado water law, and these have been capped in recent years in order to meet compliance. Currently, irrigation takes place on private inholdings (TNC lands managed by 
Ranchlands/Zapata Partners) within the park boundary. Currently, the NPS Water Resources Division is preparing an analysis on the possible effects of cessation of irrigation and water diversions on the Medano Ranch (Phyllis Pineda-Bovin, Great Sand Dunes National Park and Preserve, written commun., April 2015).

\section{Riparian Wetlands}

Riparian wetlands are diverse in terms of ecological functioning, hydrology, and vegetation composition. Because of the linear and interconnected nature of riparian environments, gradients in important environmental variables (water table depth, elevation, soil characteristics, and flood disturbance) and resulting vegetation patterns vary both laterally and longitudinally (Friedman and others, 2006; Schweiger and others, in press). Channel migration and episodic floods along meandering rivers with broad floodplains result in pulses of woody plant establishment creating patches of different age cohorts (Shafroth and others, 1998; Cooper and others, 2003). The principal characteristic unifying riparian wetlands is the presence of unidirectional moving water and a connection, at least part of the time, to lotic or lentic surficial hydrology. Surface flows within riparian wetlands are important as they have the potential to erode and transport sediment, with the potential energy contained in flowing water a key variable influencing ecosystem structure and function. The frequency, magnitude, and energy of floods affect all ecological processes in riparian wetlands from nutrient cycling to plant establishment (Schweiger and others, in press).

The vegetation of riparian wetlands is highly variable. Along larger mid-elevation montane streams, and lower in the foothill valleys, riparian wetland is dominated by cottonwoods, with shrubs such as red-osier dogwood (Cornus sericea) and coyote willow and diverse herbaceous canopies. Surface water and floods are critical to the healthy functioning of riparian areas. Water tables along intermittent and ephemeral streams often drop well below stream channels, limiting the distribution of hydrophytes (except deep-rooted phreatophytes like cottonwoods, tamarisk, or upland species tolerant of low soil moisture) (Goodwin and others, 1997). Many headwater streams receive perennial groundwater inputs from side slopes, maintaining high base flows. Stream and riparian wetlands in GRSA are functionally unique owing to the high porosity of underlying sand (Wurster and others, 2003).

The Salas vegetation map does not have a riparian wetland category, and several vegetation types are classified in the ROMN wetland map as riparian wetlands-Emergent Marsh, Narrowleaf Cottonwood Temporarily Flooded Woodland Alliances, Narrowleaf Cottonwood Sand Dune Woodland Association, and Coyote Willow Temporarily Flooded Shrubland Alliances. Because cottonwood and willow are addressed separately in this document, their inclusion in the riparian wetlands category is redundant and would not reflect their unique nature as riparian areas with a woody shrub or tree overstory. However, those areas along Big and Little Spring Creeks that have a highly productive herbaceous layer (see description of Emergent Marsh in the section on wet meadows), would be appropriate for sampling of riparian wetlands. All of the sites that Schoenecker (2012) termed "wet meadows" fall in this riparian wetlands category.

\section{Marshes}

Marshes are depressional wetlands characterized by inundation on a relatively frequent basis, often with deep standing water and large fluctuations in species composition commonly occurring over relatively short time scales (Schweiger and others, in press). The vegetation of marshes is often limited to species that are capable of rooting in mucky, saturated soil and can tolerate submersion and occasional dry periods and include monotypic freshwater communities dominated by hydrophytes such 
as cattail (Typha latifolia), common threesquare (Schoenoplectus pungens), and mare's-tail (Hippuris vulgaris), and in saline playa environments halophytes such as bulrush (Scirpus nevadensis) and saltgrass. Marsh hydrology can be extremely variable and frequently includes both prolonged periods of inundation as well as extended dry periods, particularly during dry years (Schweiger and others, in press).

Most areas identified on the Salas vegetation map as Emergent Marsh are also classified as marsh by ROMN (fig. 5) with the exception of those areas along the upper reaches of Big Spring and Little Spring creeks that are identified as riparian wetlands by ROMN. However, ROMN has only eight WEI sample sites in marsh and only half of these sites align with the Salas and others (2011) emergent marsh type.

\section{Grazing Effects in Wetlands}

The effects of grazing on herbaceous communities have been found to be variable based on the metric used, the evolutionary history of grazing, precipitation, relative annual net primary productivity, season of grazing, and grazing intensity (Milchunas and Lauenroth, 1993). Gass and Binkley (2011) found that intensive elk grazing was correlated with drier more compacted soils, soil nutrient loss, and reduced plant biodiversity in montane wetlands in Rocky Mountain National Park in Colorado.

Whereas grazing has been found to accelerate weed invasions (Hobbs and Huenneke, 1992; Fleischner, 1994), other studies have found that grazing increases local species richness and reduces exotics on a local scale in some systems (Frank, 2005). Stohlgren and others (1999) found that grazing had little effect on native species richness or on the accelerated spread of exotic plants at landscape levels (though effects at local levels were variable), and that soil characteristics, climate, and disturbances (fire, flooding, insect and disease outbreaks) likely have a greater effect on plant species diversity than grazing does. In this landscape, pollen in sediment deposits indicates an increase in the exotic plant Russian thistle (Salsola spp.) coincident with increases in the dung fungus, Sporomiella, associated with the introduction of cattle and sheep grazing in the late 1800s (Jodry and Stanford, 1996). Anecdotal evidence also indicates increases in Canadian thistle (Cirsium arvense) inside the exclosures used by Schoenecker (2012) where habitat has now been released from herbivory pressure (C. Pague, TNC, written communication, 2015).

Wetland areas were favored by both elk and bison (Schoenecker and others, in press; Kate Schoenecker, Ecologist, USGS, Fort Collins Science Center, unpublished data). The estimated herbaceous offtake in wet meadow wetlands (Schoenecker [2012] called these mesic meadows) was 43.9 percent in the summer and 63.7 percent in the winter (measured in 2006 and 2008; annual herbaceous offtake data not available). In streamside riparian wetlands, herbaceous offtake in areas grazed by elk and bison averaged 45 percent of production in summer and 45 percent of standing crop in winter, or roughly 70 percent removal of total herbaceous production during the year (Schoenecker, 2012). Herbaceous offtake was lower in riparian wetlands off the bison range with 31 percent herbaceous offtake in the summer and 17 percent during the winter for an estimated total of 43 percent removal of total herbaceous production during the year (Schoenecker, 2012). Yet all streamside riparian wetlands had higher nitrogen yield and greater plant production in grazed grasses than grasses protected from grazing for $4 \mathrm{yr}$, suggesting these riparian wetlands were resilient to the high level of herbivory they received during 2005-2009.

Herbaceous offtake levels (greater than 70 percent annually) on riparian wetlands on the bison range indicate a very heavy level of ungulate use compared with data from grasslands around the world (Milchunas and Lauenroth, 1993). Between 2008 and present, the Medano Ranch bison herd size increased to a maximum of approximately 2,500 animals and then decreased to roughly 1,700 
(Schoenecker, 2012). Ranchlands/Zapata Partners monitor five transects in wet meadows every $3 \mathrm{yr}$ (most recently in 2012) and calculate a grazing response index (GRI, Reed and others, 1999). They estimated ungulate use on wet meadows ranged from 5 percent to 90 percent depending on location and year (Zapata Partners, 2013, unpublished data). GRI was -2 at all sites in 2012, which was lower than when sampled in 2009, likely due to lower precipitation and higher use at some sites (Zapata Partners, unpublished data). The GRI combines frequency, intensity, and season of grazing plus annual precipitation to determine an index value from -4 to +4 where positive numbers are indicative of better range condition.

Schoenecker (2012) found these areas to be highly resilient to changes in grazing levels during 2005-2009 as measured by vegetation productivity (which was greater with grazing) and no observed shifts in species composition occurred after $4 \mathrm{yr}$ of exclosure treatment. However, the 4-yr timeframe of her treatments may have been too brief to detect a treatment effect of grazing exclusion on species composition. Similarly, Przeszlowska (2006) found increased carbon (C) and nitrogen (N) mineralization rates in riparian wetlands grazed by bison and elk compared to riparian wetlands grazed only by elk, which can lead to increased soil fertility and higher forage quality in these areas.

The strong affinity of grazers for wetlands makes these communities susceptible to invasion of non-native plant species. Variables that will likely provide the most information about grazing effects on wetland communities include measures of percent bare ground, measures of mean invasiveness and mean conservatism scores (Herrick and others, 2009a, 2009b; Schweiger and others, in press). Mean conservatism scores assign values from $0-10$ to each species present: low scores for exotic and ruderals, intermediate scores for competitors and matrix species, and high scores for native species that are highly dependent on remnants of habitat (Rooney and Rogers, 2002; Rocchio, 2007). An assessment of floristic quality of wet meadows of the Medano Ranch determined that the area was less disturbed than nearby Zapata Ranch, which has been subjected to higher rates of livestock grazing and which is generally drier (Elin Franzen, Colorado State University student, 2008, unpubl. undergraduate honors thesis). However, available data indicate that mean $\mathrm{C}$ (coefficient of conservatism) scores on low elevation wetlands in GRSA were generally less than 5, indicating that these communities have undergone a moderate degree of disturbance, likely due to historic grazing and irrigation practices (E.W. Schweiger, Ecologist, U.S. National Park Service, Inventory and Monitoring Program, Rocky Mountain Vital Signs Monitoring Network, oral commun.).

Data from pilot studies by ROMN suggest that wetlands in the study area may be degraded (using a multimetric index based on numerous variables related to invasive and native plant cover, soil conditions, ground cover, and others) with up to half the salt flat and wet meadow wetlands on the sand sheet in a non-reference state. There appears to be an association between reduced wetland condition and ungulate habitat use, but more work is needed (E.W. Schweiger, Ecologist, U.S. National Park Service, Inventory and Monitoring Program, Rocky Mountain Vital Signs Monitoring Network, oral commun.).

Although GRSA riparian wetlands appear resilient to year-round grazing by ungulates in some studies (vegetation productivity, nitrogen yield, species diversity, N mineralization rates, Schoenecker [2012]), other preliminary work suggests some substantial degradation may occur in wetland vegetation condition or ecological integrity with higher levels of ungulate habitat use (Schweiger and others, in press), while effects on other variables are unknown (for example, soil compaction). Increases in the number of grazers or changes in environmental conditions (drought, warming temperatures) may eventually lead to negative effects in these apparently grazing-adapted communities. These communities also contain plant species that are rare in this landscape, such as slender spiderflower and canyon bog orchid (Platanthera sparsiflora var. ensifolia) and which are a high priority for grazing monitoring. The 
greatest considerations in wetland communities are likely to be invasion of non-native plant species and soil compaction and erosion due to trampling in areas where grazers concentrate. Also of potential importance in these areas is habitat for ground-nesting waterbirds, particularly in the wetlands around Dollar and Cotton Lakes. Grazers can have both direct (trampling and disturbance) and indirect (effects on habitat, forage, and predation) effects on ground-nesting birds. Habitat characteristics such as vegetation cover and height can be influenced by removal of plant material and trampling of plants, leading to shorter and sparser vegetation cover (Powers and Glimp, 1997) that may make them less suitable for some species.

While Schoenecker's conclusions of grazing resilience appear contradictory to ROMN's observations of wetland degradation, it is important to note several differences between these studies. Schoenecker's research was conducted in 2005-2008, during a time when the bison population on the Medano Ranch was approximately 1,200-1,500 animals and in the early years of an extended drought which started around the year 2000. Her research was aimed at determining grazing effects on plant productivity and species composition in specific areas that were present both on and off the bison range and did not include any salt flat wetlands. A suite of factors including vegetation community composition, soil characteristics, water chemistry, and groundwater depth and dynamics was measured by the ROMN WEI program. The ROMN data were collected during a single year (2010) after the bison population had increased to 2,500 animals in 2009 and when the cumulative effects of a decade of drought conditions were likely to be having a significant effect. Additionally, the ROMN sample set included a much larger and more diverse sample of sites, including several vegetation types on the sand sheet identified by the Salas vegetation map as greasewood, playa, and rabbitbrush, whereas the Schoenecker (2012) study reported results strictly from streamside riparian wetlands. These differences in timing and scope limit the comparability of the two studies.

The number of interdunal wetlands at GRSA declined more than 80 percent from 1936 to 1979 , then doubled again by 1995 for an overall loss of 52 percent of all interdunal wetlands from 1936 to 1995 (Hammond, 1998). However, the loss of interdunal wetlands was related to changes in the water table due to channel incision and lowered average stream flow in Sand Creek (Wurster and others, 2003). These authors concluded that many interdunal wetlands were ephemeral over a time-scale of several decades. Existence and persistence of interdunal wetlands are dependent on hydrology and longterm climate patterns that may have as much as a 20-yr lag effect. As such, inclusion of interdunal wetlands in a grazing monitoring plan should be carefully considered and sample designs and data interpretation should be mindful that the existence of these particular wetlands is highly dependent on factors beyond the scope of ungulate management. Ungulate herbivory may accelerate the loss of vegetation in interdunal wetlands, and they have been found to be highly preferred by ungulates. In a 2006 survey of previously mapped (Hammond, 1998) interdunal wetlands, Schoenecker (2012) found that at 6 of 19 interdunal wetland sites where willow were present, 70 percent of twigs of interdunal willow plants were browsed.

Park managers will have to carefully define what constitutes a wetland for the purposes of the ungulate management plan, which wetland types to include, and consider which aspects of wetland community integrity are important in terms of determining grazing effects. At a minimum, the most widespread wetland types, salt flats and wet meadows should be included in sampling. ROMN has already established many sites for monitoring wetland ecological integrity (WEI) in these lower elevation wetlands at GRSA. The monitoring conducted by the ROMN WEI program provides a rigorous sample of wetlands and GRSA managers might use this program (Schweiger and others, in press) in part to implement wetland grazing monitoring as well. When and where possible, use of sites that are part of the ROMN WEI sampling would prevent duplication of work, expand data collection, 
and potentially save resources for both programs. Some of the measures necessary to determine grazing effects on wetlands in GRSA might be already included in sampling being conducted by ROMN. Additional grazing-relevant measures, especially of explicit ungulate use of sites, would need to be added. Sharing crews for establishment and monitoring of sites could be mutually beneficial and prevent added non-natural disturbance to sites through visitation by separate crews. Sample design considerations will entail adding sites to appropriately distribute an adequate number of sites based on future ungulate presence on the landscape as a result of management decisions related to the UMP.

The protocols and plan for ROMN WEI monitoring are currently being finalized (Mike Britten, Program Manager, U.S. National Park Service Inventory and Monitoring Program, Rocky Mountain Vital Signs Monitoring Network, written commun., August 2014). There are eight exclosures in GRSA that were established by the USGS/NPS study in 2005 in this wetland vegetation type. Continued monitoring within these exclosures may be useful to ROMN to capture the characteristics of ungrazed wetlands as part of developing a gradient of disturbance and response (E.W. Schweiger, Ecologist, U.S. National Park Service, Inventory and Monitoring Program, Rocky Mountain Vital Signs Monitoring Network, February 2014, unpublished presentation). For this reason, park managers would be wise to discuss with ROMN ecologists the usefulness of continued maintenance of the wetland exclosures.

If, and when, TNC ceases agricultural uses of the Medano Ranch and these lands are transferred to NPS management, the GRSA GMP (U.S. Department of the Interior, 2007) proposes cessation of irrigation in order to restore natural hydrologic flows. However, before surface irrigation is discontinued on the Medano Ranch, a study will be conducted to better understand how this action might affect wetlands, groundwater supplies, federal water rights, and the Closed Basin Project. If this action were to occur, it is expected that long-term, moderate to major effects from cessation of agricultural irrigation and water diversions would occur (U.S. Department of the Interior, 2007). Geographic changes in vegetation communities resulting from hydrologic modification could influence the distribution of ungulates on the landscape as animals disperse to or concentrate in their preferred habitats. These potential changes will be important in selecting sites for monitoring effects of ungulate herbivory or interpreting the results of monitoring as hydrologic changes manifest on the landscape.

Given the amount of direct and indirect human influence on many GRSA wetlands from decades of livestock grazing and water manipulation for irrigation, coupled with potential future hydrologic modification to support water-law compliance, determining how to include this type in grazing monitoring will be complicated. Measures of species composition and abundance, amount of bare ground, gaps between plants, and soil characteristics (bulk density and infiltration) would all be useful metrics to determine the extent and severity of any grazing or habitat management actions.

\section{Upland Shrub and Grassland}

Rubber rabbitbrush (Ericameria nauseosa) is generally considered to be a grazing-resilient species and can be an important browse species for pronghorn and deer, and to a lesser extent, elk (Tirmenstein, 1999; U.S. Department of Agriculture, 2014). It is likely used somewhat by elk, but may be a more primary component of pronghorn and deer diets (Tirmenstein, 1999; Boccadori and others, 2008). Greasewood is generally considered grazing resistant and can be an important browse species for pronghorn and deer, and to a lesser extent, elk (Anderson, 2004; U.S. Department of Agriculture, 2014). Bison do not typically browse woody plants to any great extent, and diet studies reveal little to no use of either shrub species by bison (Singer and Norland, 1994; Kate Schoenecker, Research Ecologist, USGS, 2014, unpublished data), though bison can cause damage to woody species through horning and rubbing (Coppedge and Shaw, 1997). 
The Natural Resources Conservation Service Ecological Site Description (ESD) for the entire San Luis Valley addresses many important aspects of upland shrub and grassland communities. In particular, it notes that during drought, greasewood had diminished vigor and increased mortality and that warm season bunchgrasses declined, but persisted (Diller and Villa, 2013). The ESD notes that on sites where rabbitbrush and greasewood are codominant, mis-management through overgrazing may lead to greasewood dominance, whereas non-use and drought can lead to rabbitbrush dominance. Rabbitbrush tends to be groundwater dependent, whereas greasewood uses groundwater during dry periods and precipitation after heavy monsoonal rainfall (Kray and others, 2012). Understory grasses use soil water that is precipitation-recharged. Because both rabbitbrush and greasewood have the ability to use groundwater, they are more likely to be affected by water table declines than by lower levels of growing season precipitation, which may allow them to persist in the face of short-term drought conditions. However, if long-term drought leads to lowered water table, mortality of both species is possible. Both shrub species tend to be grazing resilient in terms of biological integrity, soil stability, and watershed function, but an eroded state can develop under recurrent early-season grazing that is exacerbated by extended drought (Diller and Villa, 2013).

Upland shrub and grassland communities make up a large component of the GRSA landscape, and it is important to be aware of their condition. It may be impractical to attempt to intensively monitor these communities because of their relative resilience to elk and bison herbivory and given the likelihood of limited resources for monitoring. A particular concern in the rabbitbrush and greasewood areas with a loose sand substrate, and for herbaceous stabilized dunes, is that grazing and drought can combine to reduce understory herbaceous plants which are holding loose sand in place. Rondeau and others (2013) found that grass cover decreased significantly during drought, as did rabbitbrush density, though rabbitbrush cover increased. Rabbitbrush is a deep-rooted species, which is likely key to its ability to thrive during and following drought. Rabbitbrush may also facilitate survival of understory herbaceous species, particularly when precipitation is below average, by modifying the microclimate (dampening temperature fluctuations, raising humidity, decreasing wind speed, reducing irradiance, and increasing soil moisture) under plant canopies (Peek and Forseth, 2003). However, when understory herbaceous plants decrease, sand movement may occur and eventually affect rabbitbrush as well through burial of shrubs in the dune or exposure of roots. Mangan and others (2004) used modeling to investigate the effects of drought and grazing on vegetation and dune stability in the Nebraska Sand Hills and found that grazing alone had little effect on vegetation, but, combined with drought, led to biomass decreases. Even low-intensity grazing coupled with drought was projected to affect both aboveand below-ground plant biomass. Their modeling indicated that declines in plant biomass brought on by drought and exacerbated by grazing could lead to sand dune mobilization, but that even sparse vegetation cover (10 percent ground cover) could be sufficient to stabilize dunes and prevent sand movement (Valdez, 1990; Mangan and others, 2004).

\section{Rabbitbrush}

Rabbitbrush communities are the most abundant habitat type on the valley floor in the study area and comprise 23,135 ha (56 percent) of the study area, including 5,281 ha on the bison range. Most of the rabbitbrush on the valley floor is identified on the vegetation map as Sandsheet Rabbitbrush Shrubland and Steppe Alliances that are defined as areas of open to moderately dense shrub steppe or shrublands dominated by rabbitbrush and occurring widely on the stabilized sand sheet and sand ramp. Winterfat (Krascheninnikovia lanata) and greasewood may be present with low cover. Substrate is deep, loose sand. Herbaceous species include Indian ricegrass, needle-and-thread grass, sand muhly (Muhlenbergia pungens), or alkali sacaton (Salas and others, 2011). Also included in this type are 
Alluvial Fan Rabbitbrush Shrubland and Steppe Alliances: some small patches of rabbitbrushdominated shrublands restricted to alluvial fans located on coarse textured gravelly or cobbly loams or sandy loams mainly to the north of the dunefield.

Rabbitbrush communities were measured in one season and had lower summer herbaceous offtake (39 percent on the bison range, 18 percent off the bison range) than wet meadow and riparian habitats (Schoenecker, 2012) These herbaceous offtake rates were comparable to rates found in other Rocky Mountain uplands heavily grazed by bison and elk (Frank and McNaughton, 1992). Winter use rates and browse rates on rabbitbrush shrubs are unknown. Both elk and bison use rabbitbrush communities roughly equal to or less than expected based on their availability on the landscape (Schoenecker and others, in press; Kate Schoenecker, Ecologist, USGS, Fort Collins Science Center, unpublished data).

\section{Greasewood}

Greasewood communities are also prevalent in the study area, totaling 3,036 ha (approximately 7 percent) of the study area including 1,846 ha on the bison range. The vegetation map (Salas and others, 2011) identifies two greasewood-dominated community types: Greasewood Sand Deposit Shrubland and Steppe Alliances as well as Greasewood Flat Shrubland and Steppe Alliance.

Greasewood communities are described as areas of open to moderately dense greasewood-dominated shrubland or steppe either on dunes and sand sheet or alluvial flats on the valley floor. Scattered rabbitbrush (E. nauseosa or Chrysothamnus greenei) are often present and may codominate. Herbaceous layer is sparse to moderate with Indian ricegrass, goosefoot (Chenopodium spp)., saltgrass, arctic rush, beardless wildrye, scratchgrass, western wheatgrass, alkali cordgrass (Spartina gracilis), and kochia (Bassia americana) present. This community type typically occurs with a relatively shallow water table. Substrate is typically alkaline and saline. The main difference between Greasewood Sand Deposit and Greasewood Flat alliances is whether the substrate is loose, deep sand or cemented with carbonates (sabkha). Indian ricegrass appears to be a good indicator of greasewood-stabilized sand sheet type (Salas and others, 2011). Our greasewood classification also includes small patches (less than $1 \mathrm{ha}$ ), which are identified as Fourwing Saltbush Shrubland Alliance which has similar characteristics to the greasewood community types.

Herbivory measurements in greasewood were also made in a single season, but indicated high summer herbaceous offtake in greasewood on the bison range (72 percent). Offtake rates outside the bison range were 18 percent, but offtake variance was very high in greasewood communities (Schoenecker, 2012). The offtake rate on the bison range appeared to be very high compared to other published values (Frank and McNaughton, 1992). Bison and elk used greasewood habitats less than would be expected based on their availability (Schoenecker and others, in press).

The ROMN monitors upland habitats in other parks and may include upland grasslands and shrublands in the future at GRSA. ROMN shrubland-monitoring protocols currently have only a minimal indicator of wildlife-herbivory included in assessments of natural disturbance. Adding measures designed to quantify grazing- and browsing-specific effects in these plant communities could be an efficient and economical means of following trends in these communities. Cooper and others (2006) found that greasewood and rabbitbrush invaded playas that were no longer subject to frequent inundation due to installation of a large irrigation project (Closed Basin Canal) and subsequent water table drawdown. 


\section{Herbaceous Stabilized Dunes}

Herbaceous stabilized dunes are described by Salas and others (2011) as vegetated dunes and sand sheets or patches (vegetated blowouts) within a shrubland or steppe, characterized by sparse to moderate (5-45 percent cover) herbaceous layer typically dominated by scurfpea (Psoralidium lanceolatum) and(or) blowout grass and Indian ricegrass, needle-and-thread grass, or sand muhly. These communities have deep, loose sand that is not cemented by carbonates (sabkha), or, if sabkha is present, a shallow sand lens covers more than half the ground surface. Herbaceous stabilized dunes cover nine percent $(3,668 \mathrm{ha})$ of the study area, including roughly 305 ha located on the bison range. Bison appear to use these habitats at a slightly greater rate than would be expected based on their availability (Schoenecker and others, in press), but elk showed little or no preference (use was less than or equal to expected based on availability of habitat) for these types (Kate Schoenecker, Ecologist, USGS, unpublished data). No measures of offtake by ungulates or effects of grazing on productivity in these communities are available for GRSA.

\section{Piedmont Semi-Desert Grasslands}

This type covers roughly 2 percent ( $881 \mathrm{ha}$ ) of the study area, mostly along the eastern edge of the study area where the foothills meet the valley floor (fig. 2), and none of this type lies within the bison range. A particularly large area of these dry grasslands occurs between the Colorado Highway 150 and Medano Creek, southeast of the dune field. Salas and others (2011) describe these areas as dry grasslands occurring on rocky alluvial fans above the sandsheet on the valley floor and in openings within pinyon-juniper woodlands. Characteristic species include blue grama (Bouteloua gracilis), needle-and-thread, with scattered rabbitbrush and prickly-pear cacti (Opuntia spp.) and sometimes low cover of mountain muhly (Muhlenbergia montana) and fescues (Festuca spp.). No measures of ungulate offtake were measured in this type, but grazing effects are likely to be similar to other semi-arid grasslands of the Intermountain West. This type is not found on the bison range.

\section{Other Plant Communities of Interest}

Although this grazing monitoring assessment focuses on plant communities found on the valley floor of Great Sand Dunes National Park, GRSA resource managers have identified two other vegetation types of concern regarding ungulate (primarily elk) herbivory effects - alpine habitats and aspen (Populus tremuloides). There is not an abundance of data specific to GRSA regarding elk herbivory in these habitats, but research has been conducted within similar habitats in the Rocky Mountains.

\section{Alpine Shrub and Herbaceous}

Alpine vegetation includes those shrub and herbaceous communities identified on the park vegetation map as Alpine Turf Alliances, Alpine Fell-Field Alliances, Alpine-Upper Subalpine Herbaceous Wetland Alliances, and Alpine Willow (Spruce) Shrubland Alliances. Alpine turf vegetation is found on gentle to moderate slopes, flat ridges, valleys, and basins where the soil has become stabilized by vegetation. Sites are windswept with a thin snowpack that melts early in spring and are characterized by a dense cover of low-growing, perennial graminoids and forbs (Salas and others, 2011). Alpine fell-fields include areas of wind-blasted alpine vegetation occurring from 3,4764,076 $\mathrm{m}$ in elevation with moderate to high cover of gravel and bare ground and sparse to moderate cover of herbaceous species dominated by cushion plants. Alpine-subalpine wetlands are found in low areas and slopes below snowfields and seeps and support a dense layer of herbaceous growth dominated 
by alpine or subalpine wetland species. Alpine shrub types include isolated patches of alpine willows (Salix planifolia and S. brachycarpa) found in mesic upland sites (Salas and others, 2011). Alpine shrub and herbaceous communities cover 1,524 ha of the 16,854 ha Preserve portion of GRSA.

Elk herbivory has been found to decrease cover and height of alpine willows (S. brachycarpa, $S$. planifolia) in other areas of the Colorado Rocky Mountains (Zeigenfuss, 2006). Long-term grazing can alter carbon dioxide and nitrogen dynamics in alpine grasslands. Grazed alpine grasslands have been found to have higher soil carbon and nitrogen concentrations, but lower plant biomass, lower grass leaf $\mathrm{N}$ concentrations, and lower early and late summer $\mathrm{N}$ mineralization rates compared to ungrazed sites (Welker and others, 2004). This could have implications for plant production and cover under high levels of herbivory in alpine areas. Grazing has also been found to decrease seed production and delay flowering in alpine forbs (Galen, 1990; Freeman and others, 2003).

Analysis of alpine willow patches on GRSA lands and adjacent U.S. Forest Service (USFS) lands found low levels of browsing and relatively healthy willows in areas near well-used recreational trails in GRSA, as compared to USFS areas, where recreational activity was low and adjacent livestock grazing was present (Zeigenfuss, Schoenecker, and van Amburg, 2011). Alpine willows were shorter and had lower cover in areas with higher levels of browsing.

The Rocky Mountain Network monitors native and exotic vegetation species (cover, presence, phenophase), soils (condition and temperature), and evidence of browsing (presence and frequency of browsing, scat, and trampling) at four alpine peak sites in GRSA on a 5-yr schedule (Ashton and others, 2010b). The four sites range from two which were receiving little or no browse pressure in 2008 to one site with moderate amounts of natural disturbance which was attributed in part to native herbivory (Ashton and others, 2010a). However, a park biologist working on this team observed elk on nearby alpine areas of the park not included in their sampling (Phyllis Pineda Bovin, Biologist, Great Sand Dunes National Park and Preserve, October 2014, oral commun.). This observation may indicate a need to survey many more alpine areas in GRSA to obtain some general knowledge of elk and other ungulate distributions and herbivory effects on these communities. Alternatively, data collected through the ROMN monitoring, as well as anecdotal evidence along trails, can be used to determine when ungulate use in high-elevation alpine habitats may be increasing to a level which necessitates grazing monitoring.

Aspen

Roughly 1,656 ha of aspen-dominated stands exist in the Preserve area of GRSA, as well as 1,545 ha of mixed aspen-conifer stands. The aspen-dominated stands are identified on the park vegetation map as Aspen Forest Alliances. Mixed aspen-conifer types are identified as Subalpine FirAspen Forest Alliance, Ponderosa Pine-Aspen Forest Alliance, Aspen-Limber Pine Forest Alliance, and Aspen-Douglas Fir Upland Forest Alliances. Small patches or scattered aspen can be found in many other conifer-dominated and deciduous riparian forest types as well. Elevation ranges from 2,507-3,555 $\mathrm{m}$ on a variety of substrates, but sites tend to be relatively mesic.

The status of aspen forests across western North America has been debated by ecologists over the past half century. Some researchers have identified declines that could lead to aspen disappearance on many western landscapes (Kay, 1997); others point to persisting or increasing stands (Romme and others, 2001; Manier and Laven, 2002) or argue that declines are apparent only at local, but not broader, scales (Suzuki and others, 1999; Barnett and Stohlgren, 2001). In the Rocky Mountains, mature aspen stands are susceptible to drought mortality. Combined with continuous, high herbivory of sprouts and young saplings, drought mortality can lead to stand collapse (Worrall and others, 2010; Zegler and others, 2012). The effects of intense herbivory on aspen stands in the Rocky Mountains are welldocumented (Romme and others, 1995; Baker and others, 1997; Suzuki and others, 1999; Dieni and 
others, 2001; Binkley and others, 2006; Binkley, 2008; Seager and others, 2013). Elk browse intensively on abundant aspen suckers following disturbances, particularly fire (Romme and others, 1995; Bailey and Whitham, 2002); elk browsing often suppresses heights of seedlings, suckers, and saplings, and ultimately prevents stand recruitment and recovery (Bartos and Mueggler, 1981).

Little information appears to exist on the state of aspen stands in GRSA. The USFS conducts aerial surveys annually to assess forest health on National Forest lands of Colorado and these surveys include the GRSA preserve (U.S. Department of Agriculture, Forest Service, Insect and Pest Detection Aerial Survey, http://www.fs.usda.gov/detail/r2/forest-grasslandhealth/?cid=stelprd3827262). The USFS 2014 survey identified roughly 52 ha of aspen stands in the Preserve that had low levels of defoliation (less than 50 percent) caused by an unknown agent, but defoliation in other stands on the nearby Rio Grande National Forest has been attributed to two insects: large aspen tortrix (Choristoneura conflictana) and western tent caterpillar (Malacosoma californicum; U.S. Forest Service, Region 2, Aerial Detection Survey Highlights for Colorado, http://www.fs.usda.gov/Internet/FSE_DOCUMENTS/stelprd3828662.pdf). A baseline survey of aspen stands in GRSA would be required to determine the current condition of stands and define the range of stand conditions for aspen on this landscape. At that point, it might be determined whether to include aspen as part of a grazing monitoring plan. In particular, the role of fire combined with herbivory should be considered when assessing potential effects from ungulates in aspen stands. GRSA has experienced several large fires over the past several years or decades.

\section{Design of an Ungulate-Vegetation Monitoring Program}

A first step in designing any monitoring program is to define the goals and objectives of the monitoring program. Therefore, these goals and objectives must be laid out in the forthcoming GRSA ungulate management plan. A goal is a brief statement of the overall purpose of the program (U.S. Department of the Interior, 2012). Objectives are more specific statements which provide additional detail about the desired outcome of monitoring and include the means by which to measure the success of ungulate management actions (U.S. Department of the Interior, 2012). Once the goals and objectives of the monitoring program have been determined, the steps of designing a monitoring plan that will meet these goals and objectives may commence.

Goals and objectives for the UMP will ultimately direct the goals and objectives set out in the ungulate-vegetation monitoring plan. Ideally, the UMP will identify indicator variables and threshold levels for those variables which indicate the need for management action. The goals and objectives of the ungulate-vegetation monitoring plan will be shaped from these broad UMP goals and objectives. For example, the monitoring plan might have a goal of assessing management actions of the UMP to determine progress toward UMP goals and objectives. As a result, objectives of the ungulate-vegetation monitoring plan to support these goals might include:

- Monitor status and trends in target vegetation types (for example, cottonwoods or wetlands) for indicator variables identified in the UMP;

- Monitor status, trends, and distribution in intensity of herbivory in targeted vegetation types;

- Identify baseline conditions and use these to set minimum thresholds for condition in targeted vegetation types;

- Monitor elk and bison population size and distribution.

These are just an example of the types of objectives park staff might include in a monitoring plan but are not meant as comprehensive, nor a priority list of objectives. Similar objectives might also include monitoring effects of grazing on rare or threatened plant or animal species, dune stability, or others. 
Ultimately, those priorities set out in the UMP will be the appropriate guide for designing the monitoring plan.

A wealth of guidance exists for designing monitoring programs (Karr, 1987; Davis, 1993; Oakley and others, 2003; Fancy and others, 2009), but the guidance provided by the National Park Service's Inventory and Monitoring Program (U.S. Department of the Interior, 2012) is ideal because it uses the same approach as ROMN's Vital Signs Monitoring Program within GRSA and other Rocky Mountain National Parks. Integration of UMP monitoring with existing monitoring programs will help expand the data collection, avoid duplication of effort and unnecessary resource damage, and conserve financial and labor resources. Once the goals and objectives have been defined, a rough budget should also be determined before further development of the monitoring program. Considerations of costs should be incorporated into designing UMP monitoring and include data collection, data management and quality assurance, training, data analysis, scientific oversight, and reporting (Caughlan and Oakley, 2001). Vegetation types and metrics to be sampled will have to be carefully considered to ensure they provide key information to determine whether management objectives are being met within limited budget frameworks.

As noted in previously, UMP monitoring must also carefully include the important environmental and anthropogenic stressors or drivers that influence vegetation condition in this arid environment. Without including these covariates, it will be difficult to isolate the role of ungulate disturbance. Because increased use of a particular area by one ungulate species may cause other ungulate species to exploit areas they previously avoided, some level of monitoring vegetation types that currently receive less ungulate use may be necessary to determine landscape-level effects of management actions aimed at redistributing elk and bison herbivory. ROMN monitoring is a good example of a program that attempts to do this by including measures of hydrology, soil and water chemistry, and various disturbance gradients with estimation of vegetation structure and response. Creation of a monitoring program that will be executed consistently and completely will maximize benefits in terms of providing scientifically credible data on which to base management decisions. Underfunded programs may have to reduce or even eliminate monitoring in some years, which may undermine the ability to detect trends.

\section{Selecting Monitoring Methods}

After determining goals, objectives, and budget, GRSA management and key collaborators will need to decide which vegetation communities and indicators will be monitored. Some of these indicators may already be highlighted in the ungulate management plan, but others may be identified during the process of creating a monitoring program. Review of existing monitoring programs being considered, in development, or in use on NPS and neighboring lands in the San Luis Valley will streamline the development of a grazing monitoring program.

All federal, state, and TNC lands within or adjacent to GRSA are engaged in various stages of vegetation monitoring. One of these programs is specifically aimed at monitoring range condition and the effects of bison grazing. Ranchlands/Zapata Partners has been monitoring their bison pasture lands on the Medano Ranch using the Land EKG® method (Orchard and Mehus, 2001) since 2007. This method has many good points but is generally aimed at balancing ecosystem health with livestock production and may not be appropriate for monitoring grazing of wild ungulates. The Bureau of Land Management and the U.S. Department of Agriculture have developed guidance specifically for monitoring grazing on western rangelands (Pellant and others, 2005; Herrick and others, 2009 a, 2009b), and many of these methods are also referenced in the Land EKG and ROMN Vital Signs Monitoring programs. 
Methods currently being used by ROMN's Vital Signs Monitoring for wetland ecological integrity (Schweiger and others, in press) and vegetation composition structure and soils in grasslands, shrublands, and woodlands (Manier and others, 2011) would be ideal for incorporation by GRSA managers into their grazing monitoring plan. These programs already collect vegetation and soils data on many variables important to assessing grazing effects, such as soil compaction, soil water content, soil erosion, vegetation cover and composition, substrate cover, invasive plants, browse measures, sapling and shrub height, shrub cover, and tree diameters. Where possible, monitoring sites already being measured by ROMN could be used to reduce the number of sites needed to be installed for grazing monitoring by the park. Another monitoring program that may prove useful is Rocky Mountain National Park's elk and vegetation monitoring program that is designed to measure response in aspen and willow communities to elk population and habitat management activities (Zeigenfuss, Johnson, and Wiebe, 2011). Some metrics in this program may be directly applicable to GRSA and can be added to the ROMN WEI site structure with relative ease.

Recently, the Baca NWR began monitoring woody browse following a method proposed by retired USGS ecologist Richard Keigley and co-authors (Keigley, R.B., Warren, Jeffrey, and King, W.J., 2009, A multi-refuge program to evaluate the effect of ungulate browsing on habitat, U.S. Geological Survey, unpublished report) which is also being considered for use at several other national wildlife refuges in the region. These methods are also being considered by the Rio Grande National Forest (Randy Ghormley, Rio Grande National Forest, August 2012, oral commun.). However, these methods are not appropriate for use with coyote willow, and will likely have limited usefulness for GRSA.

\section{Sampling Design and Site Selection}

The current park vegetation map (Salas and others, 2011) is a good starting point for delineating vegetation that is common, in large patches, or easily distinguished (cottonwood for example), but it may not be suitable for site selection for all vegetation types. Rare vegetation types, such as willow, are often under-represented. Wetland areas are misclassified, or the classifications do not include the detail required to delineate wetland areas properly. The sampling design must allow for site level adjustment. For example, if willow is included among the vegetation types to be monitored for grazing effects, a detailed inventory of willow communities along all creeks in the study area will be necessary to allow for the best monitoring of change in the overall extent and health of willow in the study area. If wetlands are to be monitored, the ROMN wetland classification should also be incorporated into the vegetation map used sampling design. A reclassified vegetation map will need to be developed when final vegetation classes for monitoring are determined since many of the current classifications would likely be combined for the purpose of monitoring ungulate herbivory effects.

Sample sizes should provide an appropriate level of power (1- $\beta)$ to detect a certain degree of change in a measured variable over time with a certain degree of confidence (1- $\alpha)$. Assessing small amounts of change with a great deal of power and confidence typically requires larger sample sizes and will have associated costs to match. As a result, sample sizes often reflect a tradeoff between cost and the ability to detect trends in measured variables over time. The selected level of power and confidence to detect trends may be dependent upon the financial and labor resources available for carrying out a large-scale monitoring program, or fewer vegetation types may need to be monitored in order to achieve a high level of power and confidence to detect change. Therefore, careful selection of vegetation communities and indicator variables to be monitored is required. Sample size can be determined in a number of ways: using existing data from the study area, using data from other areas or studies, using published tables, or using formulas to calculate sample size. In this case, data for a subset of indicator 
variables exists from the Schoenecker (2012) study and ongoing work by ROMN will provide good data to parameterize power models.

A good sampling design requires appropriate, unbiased distribution of sampling sites throughout the landscape and within target populations to be sampled. Stevens and Olsen (2004) developed the generalized random tessellation sampling (GRTS) method which produces a selection of sample sites that is spatially balanced over the extent of the study area (including any subdivisions - for example, to separately measure areas with and without bison grazing), while still maintaining randomization.

Designs employing GRTS are created using a combination of ArcGIS and R programming (Kincaid, 2012). ROMN wetland monitoring sites were mostly selected using GRTS design with wet meadow and salt flat wetlands on the sand sheet as the target population. For the UMP design, the valley floor regions within the GRSA boundary could be extracted from the reclassified vegetation map and these areas could be split into those currently grazed by bison and those grazed primarily by elk. The most efficient UMP design would integrate or expand upon the ROMN wetland design. A temporal or revisit design is also important for efficient and meaningful data collection and interpretation. While repeat sampling is important to detecting change in variables over time, sampling too often within a timeframe that is too short for detectable change to occur wastes time and money (for example, measuring changes in vegetation species composition on an annual basis). However, some measured attributes may be variable over short time periods, and capturing this variability over shorter intervals may provide insight into other processes which influence the measured variables (for example, the influence of growing season precipitation on plant productivity, or phenological differences between cool-season and warmseason vegetation). There are many different temporal revisit designs that should be considered (Urquhart and Kincaid, 1999; Larsen and others, 2001) with the final approach balancing cost and temporal patterns in the core variables being measured.

\section{Baseline Data Collection}

Baseline data measures should be collected at the time of site establishment; however, some measured variables are seasonally dependent, in which case all sites of a particular vegetation type should be revisited during the same time period to collect data. Habitat and vegetation conditions have likely changed since the conclusion of both the USGS ungulate herbivory study (Schoenecker, 2012) and the initial data collection by ROMN. Drought has continued for many of the intervening years and bison and elk populations have varied throughout this period. Use of baseline data collected at the outset of the monitoring program would be most appropriate for setting or adjusting any thresholds identified for triggering ungulate management actions. An inventory of cottonwood stands should be conducted if the park desires to monitor loss of overstory cottonwood canopy on a landscape scale. It may be possible to use remotely sensed data to conduct this inventory, and, if aerial photography or satellite data with fine enough resolution are available over recent decades, this could provide insight into trends in canopy health over time. An analysis of aerial photography as far back as data is available would also allow park managers to determine if any expansion or loss of cottonwood stands over the last 50-70 yr on lower Sand Creek or Deadman Creek was in response to human alterations of the hydrology of these creeks.

\section{Conclusion}

Development of a grazing monitoring program for Great Sand Dunes National Park and Preserve will involve evaluation and determination of vegetation communities of interest, selection of goals for vegetation condition, selection of objectives to assess success of ungulate management activities, and 
design of a monitoring program that will effectively measure progress toward those goals. The grazing monitoring program would ideally be used to adapt ungulate management actions to continue toward achievement of vegetation condition goals.

\section{Acknowledgments}

We appreciate the support and cooperation of Fred Bunch, Phyllis Bovin, and Andrew Valdez of GRSA. We thank Duke Phillips and Jeff Gossage of Zapata Partners/Ranchlands, and Mike Britten and Billy Schweiger of ROMN for providing data and information on their work in GRSA. Sarah Beck, Tracy Mask, and Sarah Garza assisted with field work. Mark Sturm (NPS) and Phyllis Bovin provided comments on early drafts of this work. Billy Schweiger (ROMN) and Therese Johnson (Rocky Mountain National Park) provided insightful reviews of the manuscript. This work was funded by the USGS-NPS Park-Oriented Biological Support (POBS) Program.

\section{References Cited}

Amlin, N.M., and Rood, S.B., 2002, Comparative tolerances of riparian willows and cottonwoods to water-table decline: Wetlands, v. 22, no. 2, p. 338-346.

Anderson, E.M., 2007, Changes in bird communities and willow habitats associated with fed elk: Wilson Journal of Ornithology, v. 119, no. 3, p. 400-409.

Anderson, M.D., 2004, Sarcobatus vermiculatus, in Fire Sciences Laboratory, Producer, Fire Effects Information System, [Online]: Fort Collins, Colo., U.S. Department of Agriculture, Forest Service, Rocky Mountain Research Station, accessed June 26, 2015 at http://www.fs.fed.us/database/feis/plants/shrub/sarver/all.html.

Ashton, Isabel, Britten, Mike, Shorrock, Donna, and Schweiger, Billy, 2010, Alpine vegetation composition, structure, and soils monitoring for Great Sand Dunes National Park and Preserve - 2009 summary report: Fort Collins, Colo., U.S. Department of the Interior, National Park Service, Natural Resource Data Series NPS/ROMN/NRDS—2010/056, accessed August 11, 2014, at https://irma.nps.gov/Reference.mvc/DownloadDigitalFile?code=376379\&file=GRSA_2009_Alpine_ NRDS2010-056.pdf.

Ashton, Isabel, Schweiger, E.W., Burke, Jennifer, Shorrock, Donna, Pillmore, David, and Britten, Mike, 2010, Alpine vegetation composition structure and soils monitoring protocol—2010 version: Fort Collins, Colo., U.S. Department of the Interior, National Park Service, Natural Resource Report NPS/ROMN/NRR - 2010/277, accessed August 11, 2014, at https://irma.nps.gov/Reference.mvc/DownloadDigitalFile?code=421722\&file=ROMN_Alpine_Proto col_2010.pdf.

Bailey, J.K., and Whitham, T.G., 2002, Interactions among fire, aspen, and elk affect insect diversityReversal of a community response: Ecology, v. 83, no. 6, p. 1,701-1,712.

Baker, B.W., Ducharme, H.C., Mitchell, D.C.S., Stanley, T.R., and Peinetti, H.R., 2005, Interaction of beaver and elk herbivory reduces standing crop of willow: Ecological Applications, v. 15, p. 110-118. Baker, W.L., 1990, Climatic and hydrologic effects on the regeneration of Populus angustifolia James along the Animas River, Colorado: Journal of Biogeography, v. 17, no. 1, p. 59-73.

Baker, W.L., Munroe, J.A., and Hessl, A.E., 1997, The effects of elk on aspen in the winter range of Rocky Mountain National Park: Ecography, v. 20, p. 155-165.

Barbour, M.G., and Billings, W.D., 1988, North American terrestrial vegetation: New York, N.Y., Cambridge University Press, 434 p. 
Barnett, D.T., and Stohlgren, T.J., 2001, Aspen persistence near the National Elk Refuge and Gros Ventre Valley elk feedgrounds of Wyoming, USA: Landscape Ecology, v. 16, p. 569-580.

Bartos, D.L., and Mueggler, W.F., 1981, Early succession in aspen communities following fire in western Wyoming: Journal of Range Management, v. 34, no. 4, p. 315-318.

Beschta, R.L., 2003, Cottonwoods, elk, and wolves in the Lamar Valley of Yellowstone National Park: Ecological Applications, v. 13, no. 5, p. 1,295-1,309.

Beschta, R.L., 2005, Reduced cottonwood recruitment following extirpation of wolves in Yellowstone's Northern Range: Ecology, v. 86, no. 2, p. 391-403.

Bexfield, L.M., and Anderholm, S.K., 2010, Conceptual understanding and groundwater quality of the basin-fill aquifer in the San Luis Valley, Colorado and New Mexico, in Thiros, S.A., Bexfield, L.M, Anning, D.W., and Huntington, J.M., eds., Conceptual understanding and groundwater quality of selected basin-fill aquifers in the southwestern United States: U.S. Geological Survey, Professional Paper 1781, p. 165-188, http://pubs.usgs.gov/pp/1781/.

Bilyeu, D.M., Cooper, D.J., and Hobbs, N.T., 2008, Water tables constrain height recovery of willow on Yellowstone's Northern Range: Ecological Applications, v. 18, no. 1, p. 80-92.

Binkley, Dan, 2008, Age distribution of aspen in Rocky Mountain National Park, USA: Forest Ecology and Management, v. 255, p. 797-802.

Binkley, Dan, Moore, M.M., Romme, W.H., and Brown, P.M., 2006, Was Aldo Leopold right about the Kaibab deer herd?: Ecosystems, v. 9, p. 227-241.

Boccadori, S.J., White, P.J., Garrott, R.A., Borkowski, J.J., and Davis, T.L., 2008, Yellowstone pronghorn alter resource selection after sagebrush decline: Journal of Mammalogy, v. 89, no. 4, p. 1,031-1,040.

Braatne, J.H., Rood, S.B., and Heilman, P.E., 1996, Life history, ecology, and conservation of riparian cottonwoods in North America, in Stettler, R.F., Bradshaw, H.D., Heilman, P.E., and Hinckley, T.M., eds., Biology of Populus and its implications for management and conservation: Ottawa, Ontario, Canada, NRC Research Press, p. 57-86.

Brand, L.A., Stromberg, J.C., and Noon, B.R., 2008, Avian density and nest survival on the San Pedro River-Importance of vegetation type and hydrologic regime: Journal of Wildlife Management, v. 74, p. 739-754.

Caplan, T.R., Cothern, Kristin, Landers, Cliff, and Hummel, O.C., 2012, Growth response of coyote willow (Salix exigua) cuttings in relation to alluvial soil texture and water availability: Restoration Ecology, v. 21, p. 627-638.

Cary, Merritt, 1911, A biological survey of Colorado: North American Fauna, v. 33, p. 1-256.

Caughlan, Lynne, and Oakley, K.L., 2001, Cost considerations for long-term ecological monitoring: Ecological Indicators, v. 1, p. 123-134.

Christie, K.S., Ruess, R.W., Lindberg, M.S., and Mulder, C.P., 2014, Herbivores influence the growth, reproduction, and morphology of a widespread arctic willow: PLoS ONE, v. 9, no. 7, article e101716, 9 p.

Colorado Division of Wildlife, 2008, Northern San Luis Valley pronghorn herd, data analysis unit PH14: Monte Vista, Colo., Colorado Division of Wildlife, 17 p., accessed February 6, 2015, at http://cpw.state.co.us/Documents/Hunting/BigGame/DAU/Pronghorn/PH14DAUPlan_NorthernSan LuisValley.pdf.

Colorado Parks and Wildlife, 2013, Elk 2013 post hunt population estimates: Denver, Colo., Colorado Parks and Wildlife, accessed October 23, 2014, at http://cpw.state.co.us/Documents/Hunting/BigGame/Statistics/Elk/2013ElkPopulationEstimate.pdf. 
Colorado Parks and Wildlife, 2014, The story of Colorado's mule deer: Denver, Colo., Colorado Parks and Wildlife, 4 p., accessed July 22, 2015 at http://cpw.state.co.us/learn/Pages/CO-

MuleDeerStory.aspx.

Cooper, D.J., Andersen, D.C., and Chimner, R.A., 2003, Multiple pathways for woody plant establishment on floodplains at local to regional scales: Journal of Ecology, v. 91, p. 182-196.

Cooper, D.J., D’Amico, D.R., and Scott, M.L., 2003, Physiological and morphological response patterns of Populus deltoides to alluvial ground water pumping: Environmental Management, v. 31, p. 215-226.

Cooper, D.J., Sanderson, J.S., Stannard, D.I., and Groeneveld, D.P., 2006, Effects of long-term water table drawdown on evapotranspiration and vegetation in an arid region phreatophyte community: Journal of Hydrology, v. 325, p. 21-34.

Cooper, D.J., and Severn, Craig, 1992, Wetlands of the San Luis Valley, Colorado-An ecological study and analysis of the hydrologic regime, soil chemistry, vegetation, and potential effects of a water table drawdown: Boulder, Colo., Report to Colorado Division of Wildlife, U.S. Fish and Wildlife Service, and Rio Grande Water Conservation District, 158 p.

Coppedge, B.R., and Shaw, J.H., 1997, Effects of horning and rubbing behavior by bison (Bison bison) on woody vegetation in a tallgrass prairie landscape: American Midland Naturalist, v. 138, no. 1, p. 189-196.

Cowardin, L.M., Carter, V., Golet, F.C. and La Roe, E.T., 1979, Classification of wetlands and deepwater habitats in the United States: U.S. Department of the Interior, Fish and Wildlife Service, FWS/OBS-79/31.

Daubenmire, R.F., 1943, Vegetational zonation in the Rocky Mountains: Botanical Review, v. 9, p. 326-393.

Davis, G.E., 1993, Design elements of monitoring programs - The necessary ingredients for success: Environmental Monitoring and Assessment, v. 26, p. 99-105.

Dieni, J.S., Smith, B.L., Rogers, R.L., and Anderson, S.H., 2001, Effects of ungulate browsing on aspen regeneration in northwestern Wyoming: Intermountain Journal of Sciences, v. 6, no. 1, p. 49-55.

Diller, K.A., and Villa, C.A., 2013, Ecological site description for major land resource unit 051: online, U.S. Department of Agriculture, Natural Resources Conservation Service, accessed November 18, 2014 at https://esis.sc.egov.usda.gov/ESDReport/fsReport.aspx?id=R051XE260CO\&rptLevel=all\&approved $=$ yes \&repType $=$ regular $\&$ scrns $=\&$ comm $=$.

Dixon, H.N., 1971, Flora of the San Luis Valley, in James, H.J., ed., Guidebook of the San Luis Basin, Colorado: Socorro, N. M., New Mexico Geological Society, p. 133-136.

Fancy, S.G., Gross, J.E., and Carter, S.L., 2009, Monitoring the condition of natural resources in U. S. National Parks: Environmental Monitoring and Assessment, v. 151, p. 161-174.

Fleischner, T.L., 1994, Ecological costs of livestock grazing in western North America: Conservation Biology, v. 8, p. 629-644.

Frank, D.A., 2005, The interactive effects of grazing ungulates and aboveground production on grassland diversity: Oecologia, v. 143, no. 4, p. 629-634.

Frank, D.A., and McNaughton, S.J., 1992, The ecology of plants, large mammalian herbivores, and drought in Yellowstone National Park: Ecology, v. 73, no. 5, p. 2,043-2,058.

Freeman, R.S., Brody, A.K., and Neefus, C.D., 2003, Flowering phenology and compensation for herbivory in Ipomopsis aggregata: Oecologia, v. 136, no. 3, p. 394-401. 
Friedman, J.M., Auble, G.T., Andrews, E.D., Kittel, Gwen, Madole, R.F., Griffin, E.R., and Allred, T.M., 2006, Transverse and longitudinal variation in woody riparian vegetation along a montane river: Western North American Naturalist, v. 66, no. 1, p. 78-91.

Galen, Candace, 1990, Limits to the distributions of alpine tundra plants-Herbivores and the alpine skypilot, Polemonium viscosum: Oikos, v. 59, no. 3, p. 355-358.

Gass, T.M., and Binkley, Dan, 2011, Soil nutrient losses in an altered ecosystem are associated with native ungulate grazing: Journal of Applied Ecology, v. 48, p. 952-960.

Goodwin, C.N., Hawkins, C.P., and Kershner, J.L., 1997, Riparian restoration in the western United States-Overview and perspective: Restoration Ecology, v. 5, p. 4-14.

Hammond, D.J., 1998, Measuring changes in areal extent of historic wetlands at Great Sand Dunes National Monument, Colorado, 1936-1995: Fort Collins, Colo., Colorado State University, M.S. thesis, $164 \mathrm{p}$.

Haukos, D.A., and Smith, L.M., 2003, Past and future impacts of wetland regulations on playa ecology in the southern Great Plains: Wetlands, v. 23, no. 3, p. 577-589.

Herrick, J.E., Van Zee, J.W., Havstad, K.M., Burkett, L.M., and Whitford, W.G., 2009a, Monitoring manual for grassland, shrubland and savanna ecosystems, volume 1-Quick start: Las Cruces, N. M., U.S. Department of Agriculture, Agricultural Research Service, Jornada Experimental Range, 36 p.

Herrick, J.E., Van Zee, J.W., Havstad, K.M., Burkett, L.M., and Whitford, W.G., 2009b, Monitoring manual for grassland, shrubland and savanna ecosystems, volume 2-Design, supplementary methods and interpretation: Las Cruces, N. M., U.S. Department of Agriculture, Agricultural Research Service, Jornada Experimental Range, 200 p.

Hobbs, R.J., and Huennecke, L.F., 1992, Disturbance, diversity, and invasion-Implications for conservation: Conservation Biology, v. 6, p. 324-337.

Horton, R.J., Kolb, T.E., and Hart, S.C., 2001a, Physiological response to groundwater depth varies among species and with river flow regulation: Ecological Applications, v. 11, p. 1,046-1,059.

Horton, J.L., Kolb, T.E., and Hart, S.C., 2001b, Responses of riparian trees to interannual variation in ground water depth in a semi-arid river basin: Plant, Cell and Environment, v. 24, p. 293-304.

Jodry, M.A., and Stanford, D.J., 1996, Changing hydrologic regimes and prehistoric landscape use in the northern San Luis Valley, Colorado: Denver, Colo., Colorado Geological Society, 11 p., accessed May 8, 2015, at http://coloradogeologicalsurvey.org/wp-content/uploads/2013/08/12.pdf.

Johnston, D.B., Cooper, D.J., and Hobbs, N.T., 2011, Relationships between groundwater use, water table, and recovery of willow on Yellowstone's northern range: Ecosphere, v. 2, no. 2, article 20.

Karr, J.R., 1987, Biological monitoring and environmental assessment-A conceptual framework: Environmental Management, v. 11, p. 249-256.

Kay, C.E., 1995, Browsing by native ungulates-Effects on shrub and seed production in the Greater Yellowstone Ecosystem, in Roundy, B.A., McArthur, E.D., Haley, J.S., and Mann, D.K., compilers, Proceedings-Wildland shrub and arid land restoration symposium, 1993 October 19-21, Las Vegas, NV: Ogden, Utah, U.S. Department of Agriculture, Forest Service, General Technical Report, INTGTR-315, p. 310-320.

Kay, C.E., 1997, Is aspen doomed?: Journal of Forestry, v. 95, p. 4-11.

Keigley, R.B., 1997, An increase in herbivory of cottonwood in Yellowstone National Park: Northwest Science, v. 71, no. 2, p. 127-136.

Keller, B.J., 2011, Factors affecting spatial and temporal dynamics of an ungulate assemblage in the Black Hills, South Dakota: Columbia, Mo., University of Missouri, Ph.D. dissertation, 391 p.

Kincaid, T.M., 2012, User guide for spsurvey, version 2.4: Corvallis, Ore., U.S. Environmental Protection Agency, Office of Research and Development, National Health and Environmental Effects 
Research Lab, Western Ecology Division, Aquatic Resources Monitoring, accessed November 18, 2014, at http://www.epa.gov/nheerl/arm/documents/design_doc/UserGuide.html.

Knopf, F.L., Sedgewick, J.A., and Cannon, R.W., 1988, Guild structure of a riparian avifauna relative to seasonal cattle grazing: Journal of Wildlife Management, v. 52, no. 2, p. 280-290.

Kray, J.A., Cooper, D.J., and Sanderson, J.S., 2012, Groundwater use by native plants in response to changes in precipitation in an intermountain basin: Journal of Arid Environments, v. 83, p. 25-34.

Krueper, David, Bart, Jonathan, and Rich, T.D., 2003, Response of vegetation and breeding birds to the removal of cattle on the San Pedro River, Arizona (USA): Conservation Biology, v. 17, p. 607-615.

Larsen, D.L., Kincaid, T.M., Jacobs, S.E., and Urquhart, N.S., 2001, Designs for evaluating local and regional scale trends: Bioscience, v. 51, p. 1,069-1,078.

Lucas, R.W., Baker, T.T., Wood, M.K., Allison, C.D., and VanLeeuwen, D.M., 2004, Riparian vegetation response to different intensities and seasons of grazing: Rangeland Ecology and Management, v. 57, no. 5, p. 466-474.

Madole, R.F., Romig, J.H., Aleinikoff, J.N., VanSistine, D.P., and Yacob, E.Y., 2008, On the origin and age of the Great Sand Dunes, Colorado: Geomorphology, v. 99, p. 99-119.

Mangan, J.M., Overpeck, J.T., Webb, R.S., Wessman, Carol, and Goetz, A.F.H., 2004, Response of Nebraska Sand Hills natural vegetation to drought, fire, grazing, and plant functional type shifts as simulated by the CENTURY model: Climatic Change, v. 63, p. 49-90.

Manier, D.J., and Laven, R.D., 2002, Changes in landscape patterns associated with the persistence of aspen (Populus tremuloides Michx.) on the western slope of the Rocky Mountains, Colorado: Forest Ecology and Management, v. 167, p. 263-284.

Manier, D.J., Shorrock, Donna, Schweiger, E.W., Ashton, Isabel, Frakes, Brent, Britten, Mike, Pillmore, David, and Burke, Jennifer, 2011, Rocky Mountain Network vegetation composition structure and soils monitoring protocol—Small park grasslands, shrublands, and woodlands - Version 1.0: Fort Collins, Colo., U.S. Department of the Interior, Natural Resource Report NPS/ROMN/NRR2011/383, 218 p.

Marín, L., Forman, S.L., Valdez, Andrew, and Bunch, Fred, 2005, Twentieth century dune migration at the Great Sand Dunes National Park and Preserve, Colorado, relation to drought variability: Geomorphology, v. 70, p. 163-183.

Meany, C.A., and Van Vuren, Dirk, 1993, Recent distribution of bison in Colorado west of the Great Plains: Proceedings of the Denver Museum of Natural History, v. 3, no. 4, p. 1-10.

Milchunas, D.G., 2006, Responses of plant communities to grazing in the southwestern United States: Fort Collins, Colo., U.S. Department of Agriculture, Forest Service, Rocky Mountain Research Station, General Technical Report RMRS-GTR-169, 126 p.

Milchunas, D.G., and Lauenroth, W.K., 1993, Quantitative effects of grazing on vegetation and soils over a global range of environments: Ecological Monographs, v. 63, p. 327-366.

Naiman, R.J., Decamps, Henri, and Pollock, Michael, 1993, The role of riparian corridors in maintaining regional biodiversity: Ecological Applications, v. 3, no. 2, p. 209-212.

Noss, R.F., LaRoe, E.T., III, and Scott, J.M., 1995, Endangered ecosystems of the United States-A preliminary assessment of loss and degradation: Washington, D.C., U.S. Department of the Interior, National Biological Service, Biological Report 28, 58 p.

Oakley, K.L., Thomas, L.P., and Fancy, S.G., 2003, Guidelines for long-term monitoring protocols: Wildlife Society Bulletin, v. 31, p. 1,000-1,002.

Olechnowski, B.F.M., and Debinski, D.M., 2008, Response of songbirds to riparian willow habitat structure in the Greater Yellowstone Ecosystem: Wilson Journal of Ornithology, v. 120, no. 4, p. $830-839$. 
Orchard, Charles, and Mehus, Chris, 2001, Management by monitoring-Land EKG monitoring approach helps variety of users assess rangeland health: Rangelands, v. 23, p. 28-32.

Painter, L.E., and Ripple, W.J., 2012, Effects of bison on willow and cottonwood in northern Yellowstone National Park: Forest Ecology and Management, v. 264, p. 150-158.

Peek, M.S., and Forseth, I.N., 2003, Microhabitat dependent response to resource pulses in the aridland perennial, Cryptantha flava: Journal of Ecology, v. 91, p. 457-466.

Pellant, Mike, Pyke, D.A., Shaver, Patrick, and Herrick, J.E., 2005, Interpreting indicators of rangeland health, version 4: Denver, Colo., U.S. Department of the Interior, Bureau of Land Management, Technical Reference TR 1734-6, 118 p.

Powers, L.C., and Glimp, H.A., 1997, Impacts of livestock on shorebirds-A review and application to shorebirds of the western Great Basin: International Wader Studies, v. 9, p. 55-63.

Przeszlowska, Agnes, 2006, Potential soil carbon and nitrogen mineralization in wetland communities of the Great Sand Dunes, Colorado: Fort Collins, Colo., Colorado State University, M.S. thesis, 27 p.

Reed, Floyd, Roath, Roy, and Bradford, David, 1999, The grazing response index-A simple and effective method to evaluate grazing impacts: Rangelands, v. 21, p. 3-6.

Rocchio, Joe, 2007, Floristic quality assessment indices for Colorado plant communities: Fort Collins, Colo., Colorado State University, Colorado Natural Heritage Program, 234 p.

Romme, W.H., Floyd-Hanna, Lisa, Hanna, D.D., and Bartlett, Elisabeth, 2001, Aspen's ecological role in the West, in Shepperd, W.D., Binkley, Dan, Bartos, D.L., Stohlgren, T.J., and Eskew, L.G., comps., Sustaining aspen in western landscapes, Grand Junction, Colo. June 13-15, 2000, Proceedings: Fort Collins, Colo., U.S. Department of Agriculture, Forest Service, Rocky Mountain Research Station, Proceedings, RMRS-P-18, p. 243-259.

Romme, W.H., Turner, M.G., Wallace, L.L., and Walker, J.S., 1995, Aspen, elk, and fire in northern Yellowstone National Park: Ecology, v. 76, p. 2,097-2,106.

Rondeau, R.J., Pearson, K.T., and Kelso, Sylvia, 2013, Vegetation response in a Colorado grasslandshrub community to extreme drought-1999-2010: The American Midland Naturalist, v. 170, no. 1, p. 14-25.

Rood, S.B., Braatne, J.H., and Hughes, F.M.R., 2003, Ecophysiology of riparian cottonwoods-Stream flow dependency, water relations and restoration: Tree Physiology, v. 23, p. 1,113-1,124.

Rooney, T.P., and Rogers, D.A., 2002, The modified floristic quality index: Natural Areas Journal, v. 22, p. 340-344.

Rose, J.R., 2012, Barriers to establishment and growth of cottonwoods in Yellowstone National Park's Northern Range: Fort Collins, Colo., Colorado State University, M.S. thesis, 62 p.

Rupert, M.G., and Plummer, L.N., 2004a, Ground-water age and flow at Great Sand Dunes National Monument, south-central Colorado: U.S. Geological Survey Fact Sheet 2004-0351, 2 p.

Rupert, M.G., and Plummer, L.N., 2004b, Ground-water flow direction, water quality, recharge sources, and age, Great Sand Dunes National Monument, south-central Colorado, 2000-2001: Reston, Va., U.S. Geological Survey, Scientific Investigations Report 2004-5027, 28 p.

Salas, D.E., Stevens, Joe, Schulz, Keith, Artmann, Mike, Friesen, Beverly, Blauer, Steve, Schweiger, E.W., and Valdez, A.D., 2011, Vegetation classification and mapping project report-Great Sand Dunes National Park and Preserve: Fort Collins, Colo., U.S. Department of the Interior, National Park Service, Natural Resource Report, NPS/ROMN/NRR—2011/341, 117 p.

Schoenecker, K.A., 2012, Ecology of bison, elk, and vegetation in an arid ecosystem: Fort Collins, Colo., Colorado State University, Ph.D. dissertation, 104 p. 
Schoenecker, K.A., Lubow, B.C., Zeigenfuss, L.C., and Mao, Julie, 2006, 2005 annual progress report-Elk and bison grazing ecology in the Great Sand Dunes complex of lands: Fort Collins, Colo., U.S. Geological Survey Open-File Report 2006-1267, 45 p.

Schoenecker, K.A., Zeigenfuss, L.C., and Nielsen, S.E., in press, Selection of vegetation types and density of bison in an arid ecosystem: Journal of Wildlife Management.

Schweiger, E.W., Gage, Ed, Driver, Katie, Shorrock, Donna, Cooper, David, Britten, Mike, and O'Gan, Laura, in press, Rocky Mountain Network wetland ecological integrity monitoring protocolNarrative, version 1.0: Fort Collins, Colo., U.S. Department of the Interior, National Park Service, , Natural Resource Report NPS/ROMN/NRR.

Scott, M.L., Shafroth, P.B., and Auble, G.T., 1999, Responses of riparian cottonwoods to alluvial water table declines: Environmental Management, v. 23, p. 347-358.

Scott, M.L., Skagen, S.K., and Merigliano, M.F., 2003, Relating geomorphic change and grazing to avian communities in riparian forests: Conservation Biology, v. 17, no. 1, p. 284-296.

Seager, S.T., Eisenberg, Cristina, and St. Clair, S.B., 2013, Patterns and consequences of ungulate herbivory on aspen in western North America: Forest Ecology and Management, v. 299, p. 81-90.

Shafroth, P.B., Auble, G.T., Stromberg, J.C., and Patten, D.T., 1998, Establishment of woody riparian vegetation in relation to annual patterns of streamflow, Bill Williams River, Arizona: Wetlands, v. 18, p. 577-590.

Singer, F.J., and Norland, J.E., 1994, Niche relationships within a guild of ungulate species in Yellowstone National Park, Wyoming, following release from artificial controls: Canadian Journal of Zoology, v. 72, p. 1,383-1,394.

Singer, F.J., Zeigenfuss, L.C., Lubow, Bruce, and Rock, M.J., 2002, Ecological evaluation of potential overabundance of ungulates in U.S. National Parks-A case study, in Singer, F.J., and Zeigenfuss, L.C., comps., Ecological evaluation of the abundance and effects of elk herbivory in Rocky Mountain National Park, Colorado, 1994-1999: Fort Collins, Colo., U.S. Geological Survey, Open File Report 02-208, p. 205-248.

Singer, F.J., Zeigenfuss, L.C., Cates, R.G., and Barnett, D.T., 1998, Elk, multiple factors, and persistence of willows in national parks: Wildlife Society Bulletin, v. 26, p. 419-428.

Stevens, D.L., Jr., and Olsen, A.R., 2004, Spatially balanced sampling of natural resources: Journal of the American Statistical Association, v. 99, p. 262-278.

Stohlgren, T.J., Schell, L.D., and Vanden Huevel, Brian, 1999, How grazing and soil quality affect native and exotic plant diversity in Rocky Mountain grasslands: Ecological Applications, v. 9, no. 1, p. 45-64.

Suzuki, Kuni, Suzuki, Harumi, Binkley, Dan, and Stohlgren, T.J., 1999, Aspen regeneration in the Colorado Front Range_-Differences at local and landscape scales: Landscape Ecology, v. 14, p. 231-237.

Swift, L.W., 1945, A partial history of the elk herds of Colorado: Journal of Mammalogy, v. 26, no. 2, p. 114-119.

Swystun, M.B., Lane, J.E., and Brigham, R.M., 2007, Cavity roost site availability and habitat use by bats in different aged riparian cottonwood stands: Acta Chiropterologica, v. 9, no. 1, p. 183-191.

Szaro, R.C., 1980, Factors influencing bird populations in southwestern riparian forests, in DeGraaf, R.M., ed., Management of western forests and grasslands for nongame birds - Workshop proceedings: Ogden, Utah, U.S. Department of Agriculture, Forest Service, Intermountain Research Station, General Technical Report, GTR-INT-86, p. 403-418.

Tirmenstein, D.A., 1999, Chrysothamnus nauseosus, in Fire Sciences Laboratory, Producer, Fire Effects Information System, [Online]: Fort Collins, Colo., U.S. Department of Agriculture, Forest Service, 
Rocky Mountain Research Station, accessed June 26, 2015 at http://www.fs.fed.us/database/feis/plants/shrub/erinau/all.html.

Urquhart, N.S., and Kincaid, T.M., 1999, Designs for detecting trend from repeated surveys of ecological resources: Journal of Agricultural, Biological, and Environmental Statistics, v. 4, p. $404-414$.

U.S. Department of Agriculture, 2014, The PLANTS Database: Greensboro, N. C., U.S. Department of Agriculture, Natural Resources Conservation Service, National Plant Data Team, accessed June 26, 2015 at http://plants.usda.gov.

U.S. Department of the Interior, 2005, Conceptual management plan-Baca National Wildlife Refuge: Alamosa, Colo., U.S. Department of the Interior, Fish and Wildlife Service, 41 p.

U.S. Department of the Interior, 2007, Final general management plan/Wilderness study/environmental impact statement - Great Sand Dunes National Park and Preserve: U.S Department of the Interior, National Park Service, accessed June 26 2015, at http://parkplanning.nps.gov/document.cfm?parkID=67\&projectID=11015\&documentID=19561.

U.S. Department of the Interior, 2012, Guidance for designing an integrated monitoring program: Fort Collins, Colo., U.S. Department of the Interior, National Park Service, Natural Resource Report NPS/NRSS/NRR-2012/545, $49 \mathrm{p}$.

U.S. Department of the Interior, 2014a, Draft comprehensive conservation plan and environmental impact statement, San Luis Valley National Wildlife Refuge Complex: Lakewood, Colo., U.S. Department of the Interior, Fish and Wildlife Service, Mountain-Prairie Region, $363 \mathrm{p}$.

U.S. Department of the Interior, 2014b, Ungulate management plan and environmental impact statement-Newsletter \#2 (preliminary draft alternatives): Mosca, Colo., U.S. Department of the Interior, National Park Service, Great Sand Dunes National Park and Preserve, 5 p., accessed June 26, 2015 , at http://parkplanning.nps.gov/document.cfm?parkID=67\&projectID=25517\&documentID=61149.

Valdez, A.D., 1990, Preliminary observations of sand mobility on the sand sheet, Great Sand Dunes National Monument, Colorado, in Schenk, C.J., ed., Hydrologic, geologic, and biologic research at Great Sand Dunes National Monument, Colorado: Proceedings of National Park Service Research Symposium No. 1., p. 182-189.

Warren, E.R., 1910, The mammals of Colorado: New York, N. Y., The Knickerbocker Press, 274 p. Welker, J.M., Fahnestock, J.T., Povirk, K.L., Bilbrough, C.J. and Piper, R.E., 2004, Alpine grassland $\mathrm{CO}_{2}$ exchange and nitrogen cycling - Grazing history effects, Medicine Bow Range, Wyoming, USA: Arctic, Antarctic, and Alpine Research, v. 36, no. 1, p. 11-20.

West, N.E., 1988, Intermountain deserts, shrub steppes, and woodlands, in Barbour, M.G., and Billings, W.D., eds., North American terrestrial vegetation: New York, N. Y., Cambridge University Press, p. $209-227$

Wiegand, J.P., 1977, Dune morphology and sedimentology at Great Sand Dunes National Monument: Fort Collins, Colo., Colorado State University, M.S. thesis, 165 p.

Wockner, Gary, Boone, Randall, Schoenecker, K.A., and Zeigenfuss, L.C., 2014, Modeling elk and bison carrying capacity for Great Sand Dunes National Park, Baca National Wildlife Refuge, and The Nature Conservancy's Medano Ranch, Colorado: U.S. Geological Survey Open File Report 20141200, 23 p., http://pubs.usgs.gov/of/2014/1200/.

Worrall, J.L., Marchetti, S.B., Egeland, Leanne, Mask, R.A., Eager, Thomas, and Howell, Brian, 2010, Effects and etiology of sudden aspen decline in southwestern Colorado, USA: Forest Ecology and Management, v. 260, p. 638-648. 
Wurster, F.C., Cooper, D.J., and Sanford, W.E., 2003, Stream/aquifer interactions at Great Sand Dunes National Monument, Colorado-Influences on interdunal wetland disappearance: Journal of Hydrology, v. 271, p. 77-100.

Zegler, T.J., Margaret, M.M., Fairweather, M.L., Ireland, K.B., and Fulé, P.Z., 2012, Populus tremuloides mortality near the southwestern edge of its range: Forest Ecology and Management, v. 282, p. 196-202.

Zeigenfuss, L.C., 2006, Alpine plant community trends on the elk summer range of Rocky Mountain National Park, Colorado-An analysis of existing data: Fort Collins, Colo., U.S. Geological Survey Open-File Report 2006-1122, 21 p.

Zeigenfuss, L.C., Singer, F.J., Williams, S.A., and Johnson, T.L., 2002, Influences of herbivory and water on willow in elk winter range: Journal of Wildlife Management, v. 66, p. 788-795.

Zeigenfuss, L.C., Schoenecker, K.A., and Van Amberg, L.K., 2011, Ungulate herbivory on alpine willow in the Sangre de Cristo Mountains of Colorado: Western North American Naturalist, v. 71, p. 86-96.

Zeigenfuss, L.C., Johnson, T.L., and Wiebe, Zachary, 2011, Monitoring plan for vegetation responses to elk management in Rocky Mountain National Park: U.S. Geological Survey, Open-File Report 20111013, 85 p., http://pubs.usgs.gov/of/2011/1013/.

ISSN 2331-1258 (online)

http://dx.doi.org/10.3133/ofr20151136 